Document downloaded from:

http://hdl.handle.net/10251/147747

This paper must be cited as:

Rivadeneira-Vera, JF.; Zambrano-Mera, YE.; Pérez-Martín, MÁ. (2020). Adapting water resources systems to climate change in tropical areas: Ecuadorian coast. The Science of The Total Environment. 703:1-18. https://doi.org/10.1016/j.scitotenv.2019.135554

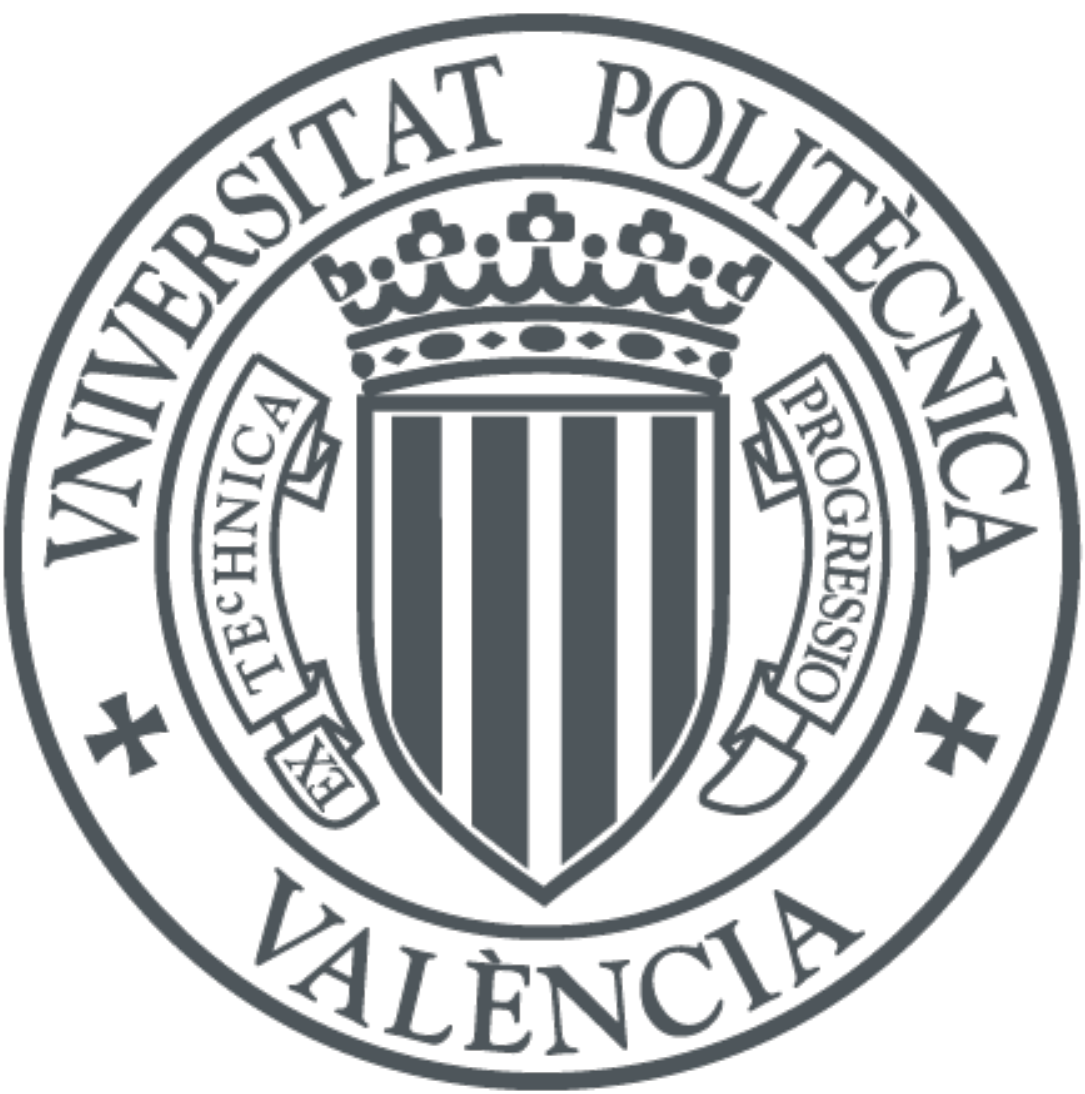

The final publication is available at

https://doi.org/10.1016/j.scitotenv.2019.135554

Copyright Elsevier

Additional Information 
Title:

\title{
Adapting water resources systems to climate change in tropical areas: Ecuadorian coast
}

\section{Author names and affiliations:}

Jonny Fernando Rivadeneira Vera ${ }^{\mathrm{a}, *}$, Yeriel Elizabeth Zambrano Mera ${ }^{\mathrm{a}}$ and Miguel Ángel Pérez-Martín ${ }^{\mathrm{a}}$. ${ }^{a}$ Research Institute of Water and Environmental Engineering (IIAMA), Universitàt Politècnica de València Camino de Vera, s/n, Valencia, ES 46022, Spain

* Corresponding Author: jonrive@doctor.upv.es , +34 671787405

\section{Present address corresponding Author:}

Camino de Vera, $s / n$

46022, Valencia - Spain.

\begin{abstract}
Climate change is expected to increase rainfall and temperature in the tropical areas of the Ecuadorian coast. The increase in temperature will also increase evapotranspiration therefore, future water balance on Ecuadorian coast will have a slight variation. Changes in precipitation patterns and evapotranspiration will produce a increase in the water requirements for current crops, so an imbalance in the water resources systems between natural resources and water demands is expected. This study present water resources management as an adaptation measure to climate change for reducing vulnerability in tropical areas.
\end{abstract}

Twelve bias-corrected climate projections are used, from: two AR5 General Circulation Models (GCMs), two Representative Concentration Pathways, 4.5-8.5 scenarios, and three time periods, short-term (2010-2039), medium-term (2040-2069) and long-term (2070-2099). These data were incorporated into the Lumped Témez Hydrological Model. Climate change scenarios predict for the long-term period both a mean rainfall and temperature increases up to $22 \%-2.8^{\circ} \mathrm{C}$, respectively. Besides, the potential evapotranspiration will increase until 12\% by Penman-Monteith method and $60 \%$ by Thornthwaite method. Therefore, natural water resources will finally have an increase of 19\% [8-30\%]. Additionally, water requirements for crops will increase around $4 \%$ and $45 \%$. 
As this research shows, in tropical regions, currently viable water resources systems could become unsustainable under climate change scenarios. To guarantee the water supply in the future additional measures are required as reservoir operation rules and irrigation efficiency improvement of system from 0.43 to 0.65 , which it involves improving the distribution and application system. In study area future irrigation areas have been estimated for 13,268 hectares, which under climate change scenarios is unsustainable, only 11,500 hectares could be expanded with a very high irrigation efficiency of 0.73 . Therefore, in tropical areas the effect of climate change on expansion projects for irrigated areas should be considered to ensure the functioning systems.

\section{Keywords:}

Climate change, RCP, Water resources management, Hydrological simulation, Water requirements, Tropical climate.

\section{INTRODUCTION}

Warming of the climate system is unequivocal, mainly due to the changes that have occurred over the last decades (IPCC, 2013). Research shows that global warming could affect the global hydrological cycle causing changes in precipitation patterns (Allen and Ingram, 2002; Held and Soden, 2006). Global and regional trends in evaporation, evapotranspiration and atmospheric water vapour content, as well as water balance studies, support the enhancement of the hydrological cycle (Huntington, 2010). Climate change is expected to intensify the frequency and severity of extreme hydrological events such as floods (MosqueraMachado and Ahmad, 2007) and droughts (Puri et al., 2011), affecting the availability of local water supplies, river discharge and seasonal water sources (Arnell et al., 2011). This translates into serious social, environmental and economic consequences, with greater repercussions in underdeveloped countries.

In Latin America, it is anticipated that until the middle of the 21st century the Amazon tropical forests would be gradually replaced by savannas and semi-arid vegetation, by arid land vegetation. In addition, losses of biological diversity could be experienced, with species extinctions, and decreases in agricultural and livestock productivity with adverse consequences for food security, increasing the number of people threatened by hunger. With refer to water, changes in precipitation patterns and the disappearance of glaciers 
would significantly affect the availability of the resource for human, agricultural and hydroelectric consumption (IPCC, 2007a). Therefore, water resources management will be confronted with enormous challenges (Georgakakos et al., 2012; Majone et al., 2012). In particular, climate change will significantly influence agricultural water management (Huang et al., 2018; Iglesias and Garrote, 2015; Nam and Choi, 2014).

Changes in water resources are particularly relevant in areas where water availability is a limiting factor for economic development (Cudennec et al., 2007). Some studies have assessed the impact of climate change projections on the hydrology of various regions throughout the world using General Circulation Models (GCMs) for projecting future climate change, and hydrological models to assess the impacts of the projected change on the water balance (Bhatta et al., 2019a; Estrela et al., 2012; Gebrechorkos et al., 2019; Kumar et al., 2017). However, due to the limited research capacity in climate and hydrological modelling in developing countries, water managers often rely on non-academic expertise to help them plan their future strategies thereby leading to weakly grounded predictions (Vergara et al., 2007). For this reason, hydro systems in tropical areas urgently require more attention to achieve sound management of water resources in the face of climate change.

The sustainability of water resources depends, to a great extent, on the adequate management and efficient use of water (Fasakhodi et al., 2010), thus planning decisions on future water resources must be based not only on demand but also on future supply and climate change projections (García-Ruiz et al., 2011). In recent years, the scientific community has placed a strong focus on adaptation to climate change due to its increasing relevance (Arnell, 2010). Most studies on adaptation (Kirby et al., 2014; Kling et al., 2014) have assessed the impacts of potential changes, and only a few of them have specifically addressed adaptation measures for coping with climate change impacts e. g. Bhave et al., (2014). The Chone and Portoviejo River Basins, in the Manabi River Basin District, are already equipped with the essential infrastructure for water management, though they have been historically affected by frequent floods and droughts (Zambrano Mera et al., 2018). Reservoirs are one of the most crucial infrastructure components for integrating water resources development and management (Liu et al., 2015). 
Adaptation measures are needed in both river basins to address the impacts of climate change. Assessments of the variation and vulnerability of water resources due to climate change are essential for future planning in agriculture (Nkomozepi and Chung, 2014). The projection of changes in water-related factors is fundamental to controlling and mitigating extreme events (Jiménez Cisneros et al., 2014; van den Hurk et al., 2016), managing water resources, ensuring food safety (Mall et al., 2017; Porter et al., 2014; Suárez-Almiñana et al., 2017) and facilitating regional development.

Many adaptive strategies have been developed to mitigate possible adverse climate change consequences. Some studies have focused on the impact of climate change on irrigation, alteration of irrigation scheduling and adaptive technology strategies, e.g., Georgiou and Papamichail, (2008) development a non-linear programming optimization model with an integrated soil water balance, to determine the optimal reservoir release policies, the irrigation allocation to multiple crops and the optimal cropping pattern in irrigated agriculture; Malek et al., (2018) study the impact of climate change on future irrigation efficiency and its partitioning between evaporative (which is consumed) and non-evaporative (which returns to the system for downstream users) losses through the development and incorporation of a mechanistic irrigation module into a hydrologic/agricultural model (VIC-CropSyst); Nam and Choi, (2014) propose an irrigation vulnerability assessment method that considers a probability distribution that uses timedependent change analyses of the irrigation water requirements by paddy fields and the water supply capacity of agricultural reservoirs; Shnaydman, (1993) study the influence of climate variations on an irrigation water resources system performance strategy. Some research has also been conducted on the derivation of operating rules for irrigation reservoirs under climate change e.g., (Ahmadi et al., 2015; Eum and Simonovic, 2010; Xu et al., 2014; Yang et al., 2016; Zhou and Guo, 2013).

Ecuador's freshwater resources are mainly generated by the wet season. As a consequence, fulfilling water requirements for agriculture, domestic purposes and ecosystems depends on the winter season. More than $80 \%$ of the annual rainfall occurs during the winter period i.e., between December-May (Zambrano Mera et al., 2018). Therefore, any change in the climate, would have a significant impact on the agricultural production, which is already now under stress due to high population growth rates and problems related to water resources management. 
This study present water resources management as an adaptation measure to climate change for reducing vulnerability in tropical areas. To evaluate the effect of climate change on water resources was using the Lumped Témez hydrological model and future simulations from two General Circulation Models CCSM4 and ECHAM6, under RCPs 4.5 and 8.5 scenarios for the 2010-2039 (short-term), 2040-2069 (medium-term), and 2070-2099 (long-term) periods. Finally, we analysed the Carrizal river exploitation system to establish the adaptation measures.

This paper is structured as follows: In Section 2, we describe the study area, in section 3 we present methodology and data set used in the study. Section 4 presents the results and discussion of the impact on water availability and the adaptation measures using fixed operating rules and irrigation efficiencies, followed by the conclusions in Section 5 . 


\section{STUDY AREA}

The Chone River Basin and the Portoviejo River Basin are located to the west of Ecuador (Fig. 1), between latitude $0^{\circ} 20^{\prime}$ to $1^{\circ} 40^{\prime}$ S and longitude $79^{\circ} 80^{\prime}$ to $80^{\circ} 40^{\prime}$ west in South America. Their drainage areas approximately 2,620 $\mathrm{km}^{2}$ and 2,150 $\mathrm{km}^{2}$, respectively. Both basins have reservoirs at their affluent an irrigation system in the middle zone, and both flow into the Pacific Ocean. Along their trajectories, water is used for human consumption, agricultural activities, fisheries and industries, although agriculture is the main economic activity along both basins.
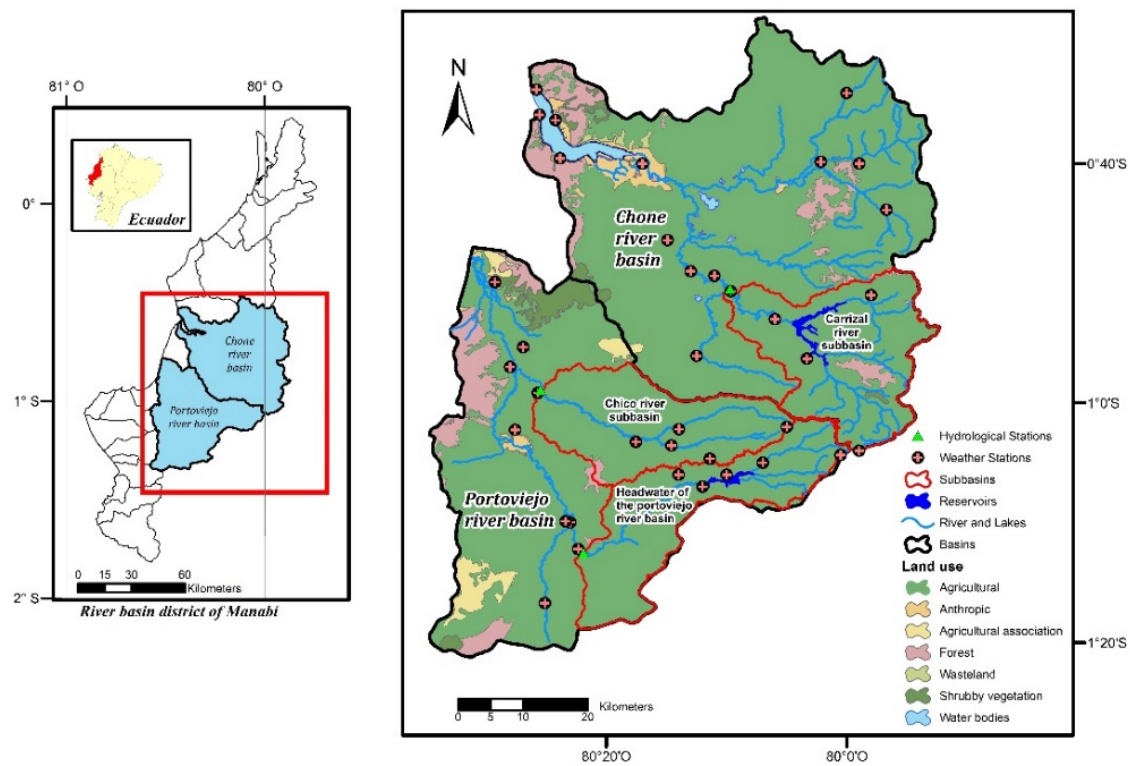

Fig. 1. Location of the Chone and Portoviejo River Basins in the Manabí River Basin District in Ecuador, includes land use.

In the study area the predominant climates are the dry/sub-humid mega thermal climate and the humid mega thermal climate, (Pourrut, 1983; Ríos et al., 2016), with two well-defined seasons: the wet season from December to May, with monthly precipitation and temperature reaching $196 \mathrm{~mm} / \mathrm{month}$ and $26.3{ }^{\circ} \mathrm{C}$, respectively, and the dry season from June to November, with precipitation levels of $19 \mathrm{~mm} / \mathrm{month}$ and a temperature of $24.8^{\circ} \mathrm{C}$, very common for a tropical climate. The average annual precipitation in both basins varies spatially; with the tributary and estuary reaching $1800 \mathrm{~mm}$ and $300 \mathrm{~mm}$, respectively, depending on the time of the year.

The Chone and Portoviejo river basins headwaters have a maximum elevation of 70 meters above sea level, the elevations are the product of various geological formations which exist in the area, Bourbon and Onzole formations are the highest outcroppings. 
The basins are directly influenced by the two phases of the ENSO event (Vargas et al., 2006; VicenteSerrano et al., 2016; Zambrano Mera et al., 2018), causing significant changes in climate variables. El Niño influences precipitations, significantly increasing their occurrence (Rossel, 1997), whereas La Niña, Niño 1 + 2 region, causes a decrease in precipitations (Zambrano Mera et al., 2018). Because of the ENSO event, the highest annual precipitation level was registered in the 1982/83, with $2855 \mathrm{~mm}$ and 1997/98 with 3352 mm, and the lowest precipitation level was registered in 1967/68 with $353 \mathrm{~mm}$. In a normal year, annual average precipitation reaches $903 \mathrm{~mm}$.

Fig. 3 b shows the seasonal variation of the Chone and Portoviejo River streamflow. In both basins, the streamflow gauge recorded a maximum in February, coinciding with the maximum precipitation of wet season and the minimum was recorded in the month of December, coinciding with the dry season.

The predominant land use in both basins is agricultural with $67 \%$, followed by forests and shrub vegetation with $18.8 \%$ and $10.3 \%$ respectively, occupying the remaining $3.7 \%$ anthropic uses, agricultural associations, wasteland and water bodies. Within this last group is the aquaculture sector that uses the water from the Chone River estuary for its purposes. The representative 67\% reflects that the greatest economic activity in the area is agriculture, an important sector in the economy of the province 


\section{METHODOLOGY AND DATA}

The methodology displayed in Fig. 2 shows the research phases, which include the following: 1) Hydrological modelling and calibration using geographical and historical climate data from the study area. 2) Statistical analysis of historical climate series and future projections of global climate models under RCP scenarios, for obtaining a bias correction coefficient that corrects future scenarios in the short, medium and long term. 3) New hydrological modelling using the projected changes, and 4) Measures for water resource management as a strategy for climate change adaptation.

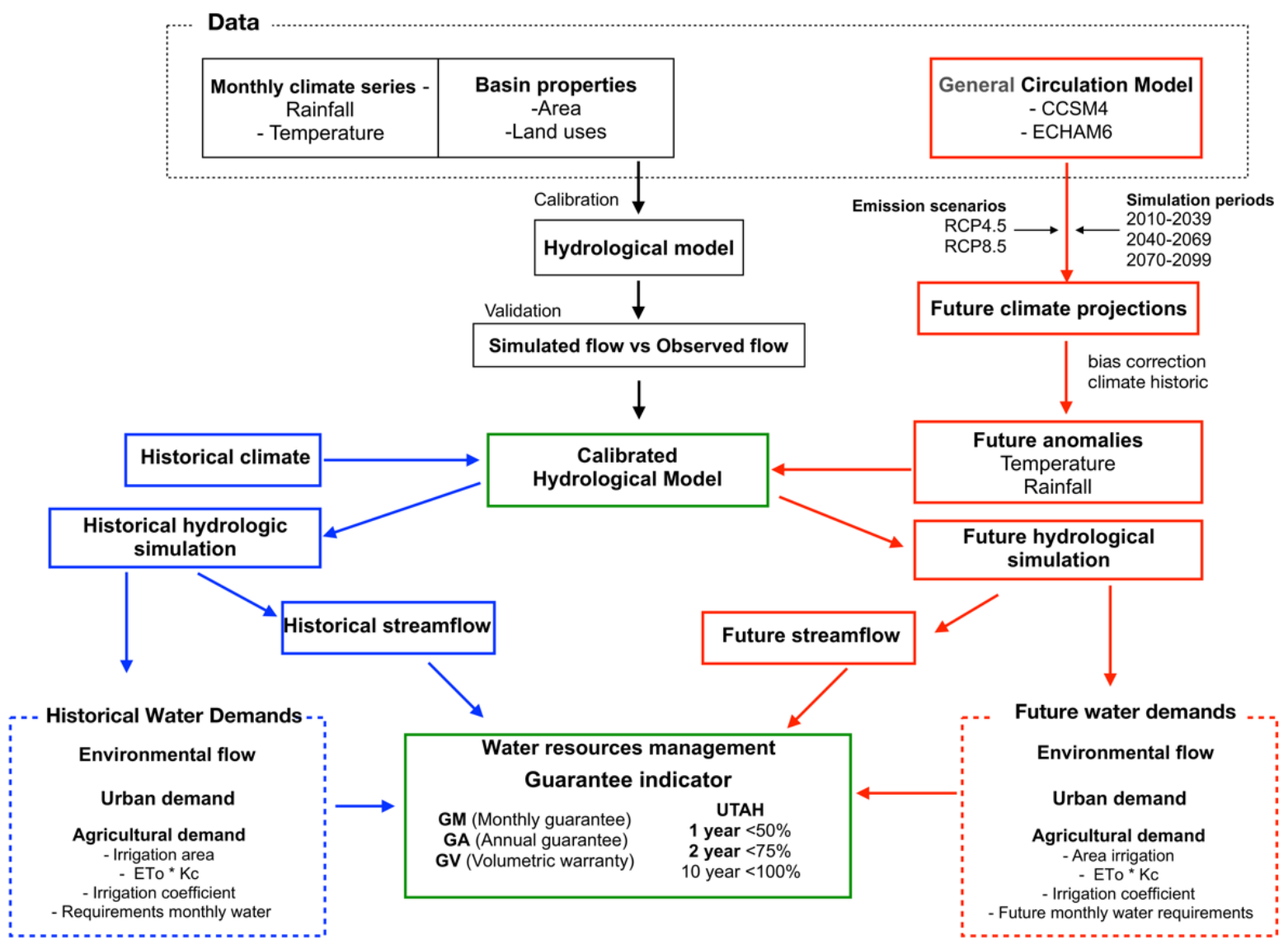

Fig.2. Methodological framework for water resources management under climate change in tropical regions.

\subsection{THE LUMPED TÉMEZ HYDROLOGICAL MODEL}

In this study, we used the Lumped Témez hydrological model for historical and future water cycle simulations. The Témez Model (Témez, 1977) is a lumped rainfall-runoff model which uses a continuous and conceptual simulation that models average monthly values in a natural regime at any given point of the hydrological network. The model belongs to the group of Aggregate River Basin Simulation Models (Estrela, 1992). Inputs to the model came from potential precipitation and evapotranspiration data, topology, subbasin 
classification and hydrogeologic unit maps. The Témez model calculates the evolution of the total hydrological system discharge for a given temporal discretization. Precipitation is considered the only input of water to the system and adds humidity to the soil. Interception and detention are not considered. Evapotranspiration reduces the amount of soil humidity. Precipitation surplus is split into surface runoff and aquifer recharge flow (Témez, 1977). Interflow is not considered. In addition, the aquifer produces a discharge flow which is a function of the depth of stored water. Finally, total discharge is the sum of surface runoff and aquifer discharge (Jódar et al., 2017). The Témez model depends on the following four parameters: Hmax, which is the maximum depth of humidity retained by the soil; Imax, which is the model parameter that limits the maximum water infiltration rate of the soil; $\mathrm{C}$, which is the proportionality parameter between the runoff threshold and the soil humidity deficit when these two variables are assumed to be linearly related; and Alpha, which is the depletion coefficient of the aquifer. The Témez model has been used in other studies (Jódar et al., 2017; Marcos-Garcia et al., 2017; Yeste et al., 2018; Zambrano Mera et al., 2018)

\subsection{DATASET}

The hydrological data were provided by the Administrative Office of the Manabí River Basin District at the Ecuadorian Water Secretariat (in Spanish SENAGUA). The hydrological stations, used for model calibration and validation, were Santa Ana, Río Chico and Carrizal, with data registered from 1962-82, 19832011 and 1962-2010, respectively.

Streamflow were calibrated (split-sample test, SS) in 2 watersheds by setting the values in the Hmax, Imax, $\mathrm{C}$ and Alpha parameters of the Témez model. The calibration period is defined to cover all the historical data available and a part of the past 20 years. We selected the Hmax values according to soil and vegetation predominance in the basins. The calibration period was 17 years (1964-1977) for the Carrizal river and 16 years (between 1983-2011) for Chico river. The Portoviejo river headwater was extrapolated with the Carrizal River data for having similar characteristics for hydrological simulations. Only the years whose registered data includes all months and a natural regime were considered in the calibration.

The validation of the model cover the period 1985/1991. Data validation was performed with the calibration analysis, Percent bias (PBIAS) which measures the average tendency of the simulated data to be 
larger or smaller than their observed counterparts (Gupta Hoshin Vijai et al., 1999), Nash-Sutcliffe Efficiency (NSE) which is a normalized statistic that determines the relative magnitude of the residual variance (“noise”) compared to the measured data variance (“information”) (Nash and Sutcliffe, 1970), and Coefficient of determination (R2) which describes the proportion of the variance in measured data explained by the model. R2 ranges from 0 to 1 , with higher values indicating less error variance, and typically values greater than 0.5 are considered acceptable (Santhi et al., 2001; Van Liew et al., 2003).

The historical precipitation and temperature data in both basins were obtained from the National Meteorological and Hydrological Institute (INAMHI, for its initials in Spanish) for the 1964-2012 period to monthly scale. These series were inserted in the Distributed Model PATRICAL (Gómez-Martínez et al., 2018; Pérez-Martín et al., 2014) with the objective of obtaining spatial climate information of the basin district for use according to the area of interest. The data were used to identify climate conditions in both basins, calibrate and validate the Lumped Témez Model, and as a starting point for simulating future climate.

The data include the Digital Terrain Model (DTM), demarcation of the water basins, water network, and geology and lithological maps, provided by the Military Geographical Institute of Ecuador (IGM, for its initials in Spanish). Soil type and land use data from the Ministry of Agriculture and Livestock (MAG) were also used for generating distributed climate time series and assigning values to calibration parameters in the Témez Precipitation-Runoff Model.

We calculated potential evapotranspiration (PET) as input to the model for historical and future simulations of hydrological variables. The calculation was based on FAO-endorsed Penman-Monteith (PET P-M) method (Allen, 1994) and the Modified Thornthwaite, (1948) (PET Th) method at a monthly scale. The Penman-Monteith method use data on radiation, air temperature, atmospheric humidity and wind speed (Allen, 1994). Thornthwaite method uses only data concerning average monthly temperatures (Ti) and daily sun hours (bi), which vary according to the month and geographical conditions.

In this study we analyzed 14 models, which are included in the fourth (AR4) and fifth (AR5) IPCC report to short (2010-2039), medium (2040-2069) and long term (2070-2099). After analyzing the graphs included in the AR4 (IPCC, 2007a) and AR5 (IPCC, 2013) and the resolution for the study area were chosen 
6 models, for those who analyzed the monthly climate pattern of the models with the monthly data observed in the study area. The correlations obtained varied from 0.67 to 0.89 , so 2 models were finally selected. We used Global Climate Models (GCM) CCSM4 (Gent et al., 2011) of $0.94^{\circ}$ latitude and $1.25^{\circ}$ length, and ECHAM6 (Stevens et al., 2013) of $1^{\circ}$ latitude and $1^{\circ}$ length, under the Representative Concentration Pathways (RCP). An RCP is a greenhouse gas concentration (not emissions) trajectory adopted by the IPCC for its fifth Assessment Report (AR5). We used scenarios 4.5 and 8.5 for projections of future climate scenarios. RCP4.5 represents the average concentration levels of greenhouse gases ( $\sim 650$ ppm CO2 eq). It is a stabilization scenario where the total radiative forcing becomes stable, shortly after the year 2100, without surpassing the projected long-term radiative forcing $\left(4.5 \mathrm{~W} / \mathrm{m}^{2}\right)$ (Clarke et al., 2007) RCP 8.5 exhibits very high concentration levels of greenhouse gases ( 1370 ppm CO2 eq); its radiative forcing reaches $8.5 \mathrm{~W} / \mathrm{m}^{2}$ for the year 2100 (Riahi et al., 2007). The scenarios were chosen by associating the CPR CO2 concentrations up to the year 2100 with the CO2 emissions of the socio-economic development models established in the Special Report on Emissions Scenarios (SRES) (IPCC, 2007a).

The spatial variability of rainfall and temperature monthly in the study area is less than $10 \%$ (mean max - min T, mean max - min P). Therefore, this study includes only bias correction. In the case of high spatial variability, it is necessary to include bias correction and downscaling technique. The bias correction technique used is in this study is the Delta Change approach (Räisänen and Räty, 2013). This technique consists in to add to real historical monthly data $\left(\mathrm{T}_{(\mathrm{obs})}(\mathrm{m}), \mathrm{P}_{(\mathrm{obs})}(\mathrm{m})\right)$ the model anomaly (increase or decrease), defined as the difference between the monthly data of the simulated scenario $\left(\mathrm{T}_{(\mathrm{scen})}(\mathrm{m}), \mathrm{P}_{(\mathrm{scen})}(\mathrm{m})\right)$ and the monthly data of the model control period $\left(\mathrm{T}_{(\mathrm{contr})}(\mathrm{m}), \mathrm{P}_{(\mathrm{contr})}(\mathrm{m})\right)$. The observed data are historical data of the study area (1964-2012); the control period data are weather observations of stations globally (1961-1990). These data are used to develop the period of future simulations according to the scenario and includes the years between 2010 - 2100. This technique has been applied in other studies (Pardo-Igúzquiza et al., 2019; Räty et al., 2014). The bias is applied to observed baseline of study area to obtain a corrected future series, which allow to reduce uncertainty. 
We simulated a water resources management system for the Chone River Sub basin through a reservoir management model that provides information regarding response to climate change under a shortterm (2010-39) and medium-term emission scenario (RCP4.5). The model searches for the minimum volume required to ensure the necessary water supply with a fixed probability or with the recognised consumptive water demand (Paredes et al., 2008). The inputs to the model correspond to reservoir data (environmental flow, urban demand, and agricultural demand), historical contribution series and future contribution series under climate change. The simulations have been performed with prioritization of urban and environmental demand; Therefore, necessary to use reservation curves to satisfy the urban demands and curves to ration the agricultural demands. 


\section{RESULTS AND DISCUSSION}

\subsection{SIMULATION MODELS}

\subsubsection{Hydrological model}

We applied the Témez model after generating the input data that were necessary for simulating historical and future flows under climate change conditions in the Chone and Portoviejo Basins. Monthly flow data from the Carrizal River in the Chone basin and from the Chico River in the Portoviejo basin were used to calibrate the Témez model. The values of PBIAS=4\%, NSE $=0.75$ and $\mathrm{R}^{2}=0.76$, in the Chone basin, indicate excellent performance in the model (Moriasi et al., 2015) concerning monthly and annual historical series. In the Portoviejo Basin, the PBIAS $=16 \%$, Nse $=0.56$ and $\mathrm{R} 2=0.87$ values indicate satisfactory performance in the model (Moriasi et al., 2015). In the Portoviejo basin, the maximum level of performance was not attained due to the lack of historical and continuous data. The results of the calibration parameters and performance levels of the Témez model are shown in Table 1. The historical hydrological simulation consisted of 48 years (1964-2012) on a monthly scale. The simulated monthly contribution served to obtain the average annual contribution of the Carrizal subbasin $\left(375 \mathrm{hm}^{3}\right)$ and the Chico subbasin $\left(89.5 \mathrm{hm}^{3}\right)$. The contribution simulation of the Portoviejo subbasin was based on the calibration parameters of the Carrizal River subbasin, because of the lack of gauging data and the similarities (geology and land use) of both basins. The average annual contribution was $227 \mathrm{hm}^{3}$. Fig. 3 a and Fig. $3 \mathrm{~d}$ shows the monthly historical simulation of the Carrizal river in the Chone river basin and the Chico river in the Portoviejo river basin. Additionally, it shows the contrast between the mean monthly flows (Fig. 3b and Fig. 3e) and the relationship with gauged flow and values obtained from the Témez model (Fig. 3c and Fig. 3f). The water balance for both basins was obtained with hydrological simulations. The parameters obtained in the simulation were as follows: average monthly precipitation, temperature, potential evapotranspiration, evaporation, infiltration, surface and subsurface runoff. Table 1 shows the simulated historical average monthly values for the hydrological variables. 


\begin{tabular}{|c|c|c|c|}
\hline \multirow[b]{2}{*}{ Subbasin } & \multirow{2}{*}{$\begin{array}{c}\text { Chone } \\
\text { River Basin } \\
\text { Carrizal } \\
\text { River }\end{array}$} & \multicolumn{2}{|c|}{$\begin{array}{l}\text { Portoviejo } \\
\text { River Basin }\end{array}$} \\
\hline & & Chico River & $\begin{array}{c}\text { Portoviejo River } \\
\text { Tributary }\end{array}$ \\
\hline \multicolumn{4}{|l|}{ Calibration Parameters } \\
\hline $\operatorname{Hmax}(\mathrm{mm})$ & 96 & 272 & 96 \\
\hline$C(\%)$ & 30 & 30 & 30 \\
\hline $\operatorname{Imax}(\mathrm{mm})$ & 90 & 160 & 90 \\
\hline Alpha (Month-1) & 0.4 & 0.4 & 0.4 \\
\hline \multicolumn{4}{|l|}{ Level of Performance } \\
\hline Bias & 1.1 & 1.2 & -- \\
\hline Relative Bias & $4 \%$ & $16 \%$ & -- \\
\hline E (Nash-Sutcliffe model efficiency coefficient) & 0.75 & 0.56 & -- \\
\hline Rs (special correlation coefficient) & 0.91 & 0.85 & -- \\
\hline r (correlation coefficient) & 0.87 & 0.8 & -- \\
\hline $\mathrm{R}^{2}$ & 0.76 & 0.64 & -- \\
\hline \multicolumn{4}{|l|}{ Simulation values } \\
\hline Subbasin area & 519 & 449 & 462 \\
\hline Mean simulated annual contribution (1964-2012) & 363.3 & 89.5 & 227.3 \\
\hline Average monthly precipitation (mm) & 120 & 79 & 95 \\
\hline Temperature $\left({ }^{\circ} \mathrm{C}\right)$ & 25.5 & 25.4 & 25.6 \\
\hline Potential evapotranspiration (mm) & 123.1 & 121.7 & 123.5 \\
\hline Evaporation (mm) & 60 & 60 & 54 \\
\hline Infiltration (mm) & 19.9 & 12 & 16 \\
\hline Surface and Subsurface runoff (mm) & 20 & 7 & 25 \\
\hline
\end{tabular}

Table 1.- Calibration values, performance and similarity of the lumped Témez Hydrological Model 

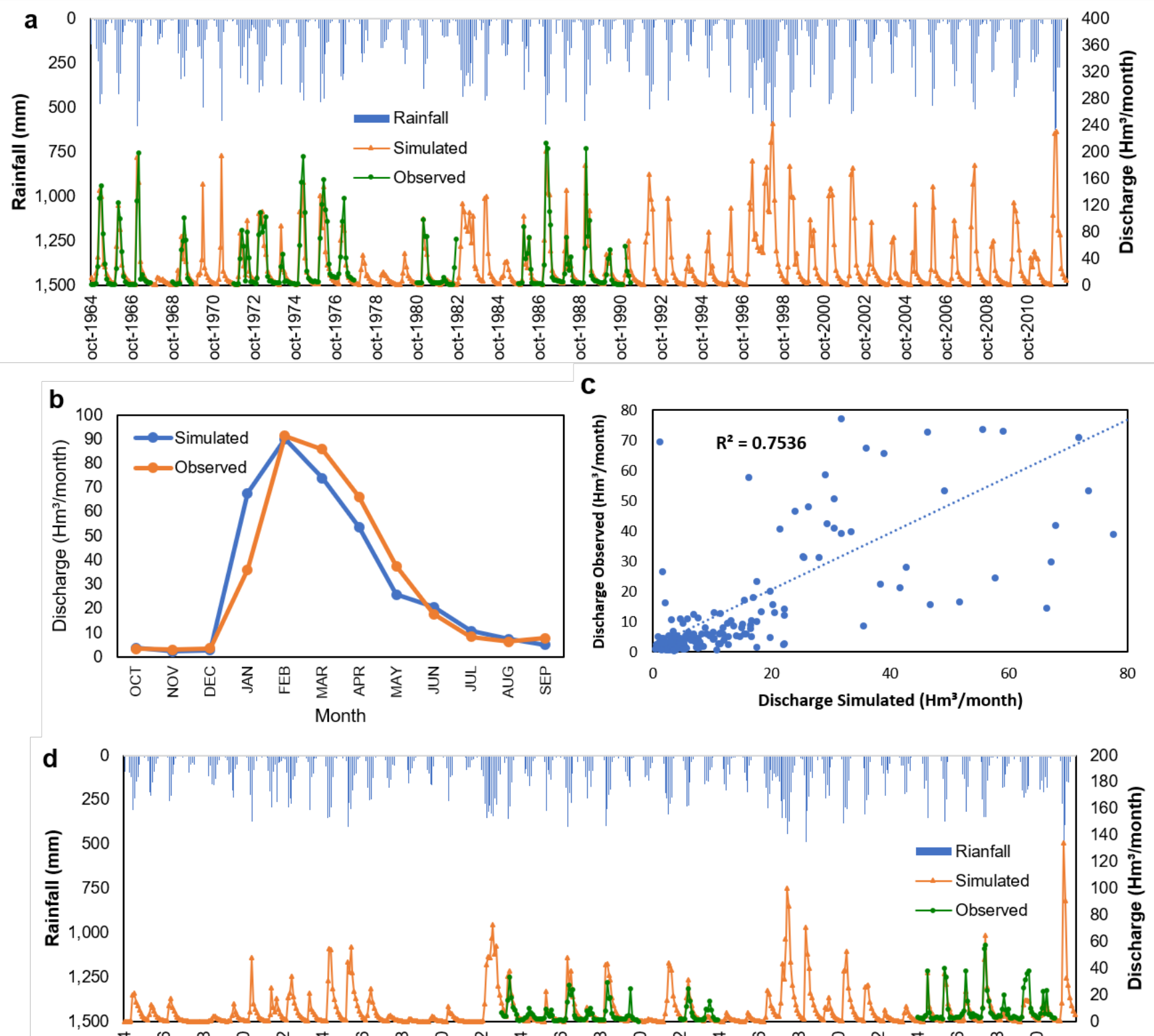

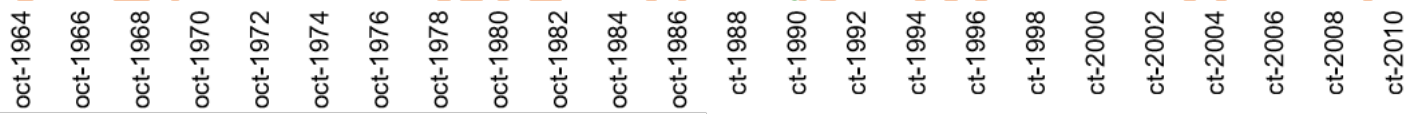
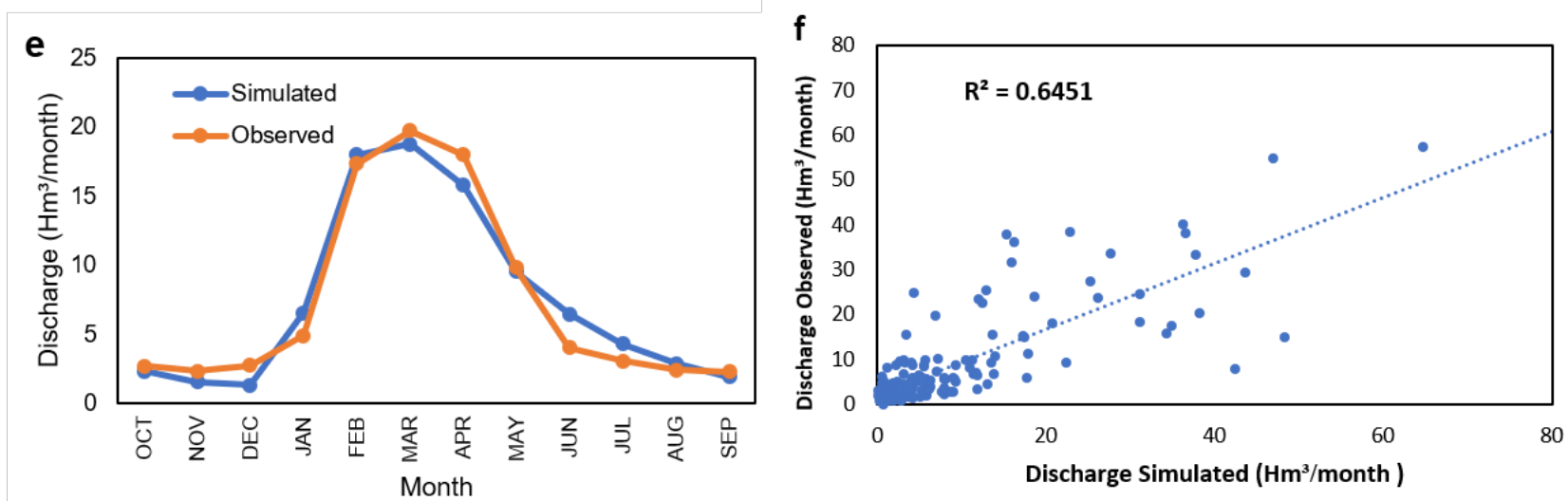

Fig. 3. Hydrological simulation based on the Témez model; a, d) monthly historical precipitation and contrast between gauged and simulated flows; $b, e)$ contrast between mean monthly gauged flow and simulated flow; $c$, f) correlation between monthly gauged flow and simulated flow for Carrizal river and Chico river. 


\subsubsection{Management model}

We approached reservoir management as a solution to ensure water availability for all types of use along the basin. The Carrizal River exploitation system, located in the Chone Basin, has a $450 \mathrm{hm}^{3}$ reservoir, with $380 \mathrm{hm}^{3}$ of useful water. The reservoir was designed and built to satisfy an annual urban demand of 20 $\mathrm{hm}^{3}$ and agricultural demand of $240 \mathrm{hm}^{3}$. Additionally, it has a pressurised irrigation system (Carrizal Chone irrigation system, built in 2007), designed to irrigate 7,250 ha in its initial phase and 13,268 ha in its operational phase; an aqueduct (built in 2015) for urban supply (18 hm³/year) and industrial supply (35 $\mathrm{hm}^{3} /$ year).

The historical hydrological simulation of the basin shows an annual contribution of $375 \mathrm{hm}^{3}$ (Table 1). Up until 2012, the system had average annual consumptions of $151 \mathrm{hm}^{3}$, of which $15 \mathrm{hm}^{3}$ correspond to the environmental flow (EF), $12 \mathrm{hm}^{3}$ urban demand (UD) and $149 \mathrm{hm}^{3}$ agricultural demand (AD). AD was based on 1) monthly water demand obtained from the water balance in the hydrological simulation $\left(60 \mathrm{hm}^{3}\right)$, 2) irrigation area (7250 ha) after completion of the initial phase of the system, 3) irrigation system efficiencies. These included, Conduction efficiency (Ec) which allows to evaluate the loss of water in the main channel from the main connection to the end point of the main channel, Distribution efficiency (Ed) which measures the loss that occurs between the side intake of the main channel, until delivery to the users of an irrigation zone and Application efficiency (Ea) which is the amount of water useful for the crop that remains in the soil after an irrigation, in relation to the total water that was applied. The Irrigation efficiency (EFi) is the relationship between the amount of water used by the plants and the amount of water supplied from the intake, the amount of water that is collected from some natural source of an irrigation system is conducted through a main channel and then derived the water through a distribution channel and finally the water is derived at plot level for some crop of the agricultural producer. The values set were EFi 0.43, Ec 0.9, Ed 0.8, Ea 0.6, and 4) Crop coefficient (Kc) defined as factor used to modify potential evapotranspiration: (1) Ratio between crop evapotranspiration (ETc) and the reference crop (ETo) when crop is grown in large fields under optimum growing conditions, or ETc $=$ Kc times ETo. (2) The ratio of the actual crop evapotranspiration to its potential evapotranspiration, The Kc value used in this study was 1.075 
and was calculated using the Crop coefficient for the mid-season stage (Kcmid). Kcmid values of the main crops in the study area (banana 1.2, cocoa 1.05, coffee 1.1, maize 1.2, pasture grass 0.75, peanut 1.15).

For calculations of future demand, we considered the following requirements: urban demand, aqueduct operation of $53 \mathrm{hm}^{3}$, agricultural demand (including an increase in future water demand due to climate change), and irrigation area expansion above the design criteria (13268 ha) of the Carrizal-Chone irrigation system, although ecological water demands remain constant. In figure 4 is showing the different demands.

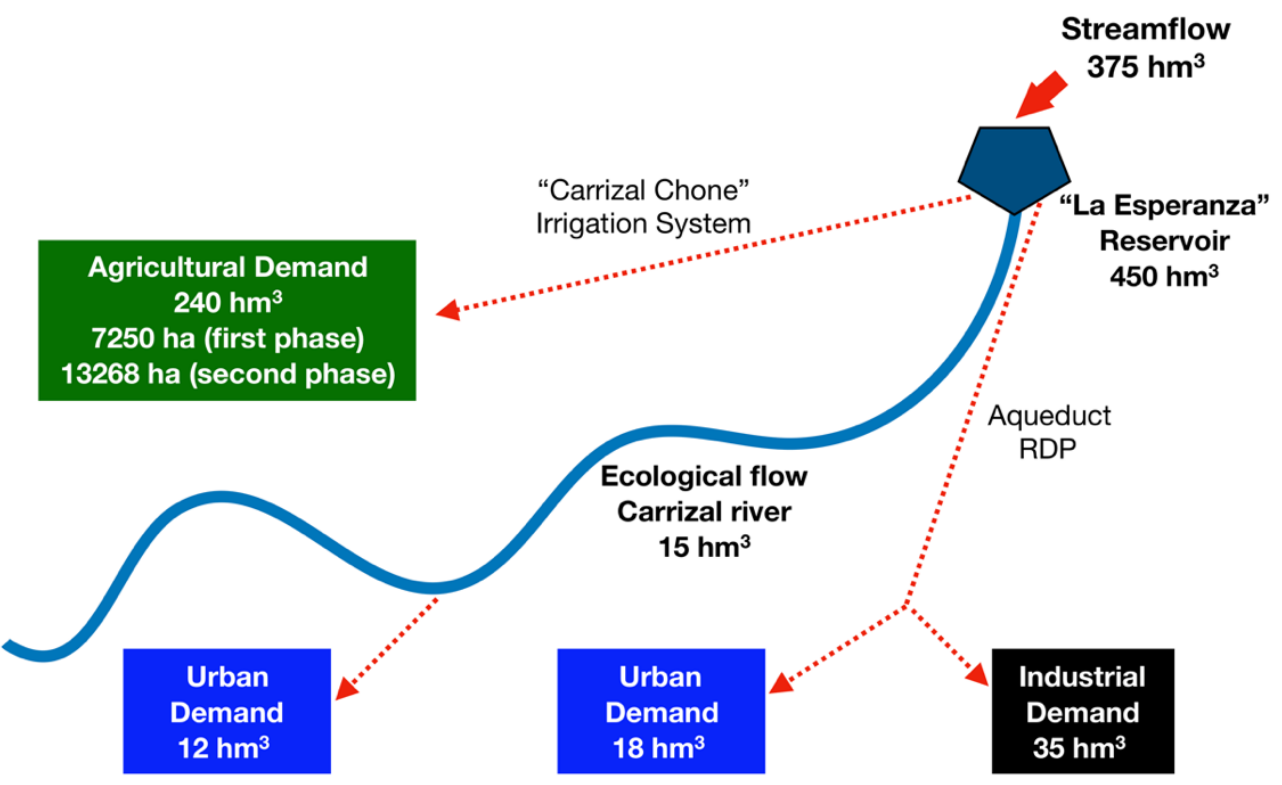

Fig. 4.- Schematic diagram of the water resources exploitation system of the Carrizal River in the Chone River Basin.

Some monthly guarantee criteria (GM) must be met to ensure the efficient management of the system: supply guarantee (GV) and annual gross supply (GA) (Estrada, 1994). Likewise, UTAH DWR criteria must be met for satisfying agricultural demand (Lall and Miller, 1988). The criteria are based on limit values for deficit scenarios that can occur in different periods (1, 2 and 3 years). Performance thresholds for these periods correspond to 50\%, $75 \%$ and $100 \%$ annual demand. The criteria used in this study can be found in the Spanish National Hydrological Plan, and are widely used for hydrological basin management, which can serve as a starting point for other countries.

The historical levels in the reservoir for the 1964-2012 period were simulated to expose if the system met the required criteria until the year 2012. We used actual measured data from the 2005-2012 period (Fig. 
5). The results showed that the system achieved $100 \%$ of the GM, GA and GV criteria, and 0\% of the UTAH $(1,2,10)$ for DU, DA and Qec criteria, therefore the system is met with the guarantee criteria. To verify the met with future guarantee criteria is necessary to consider effect of climate change on demands.

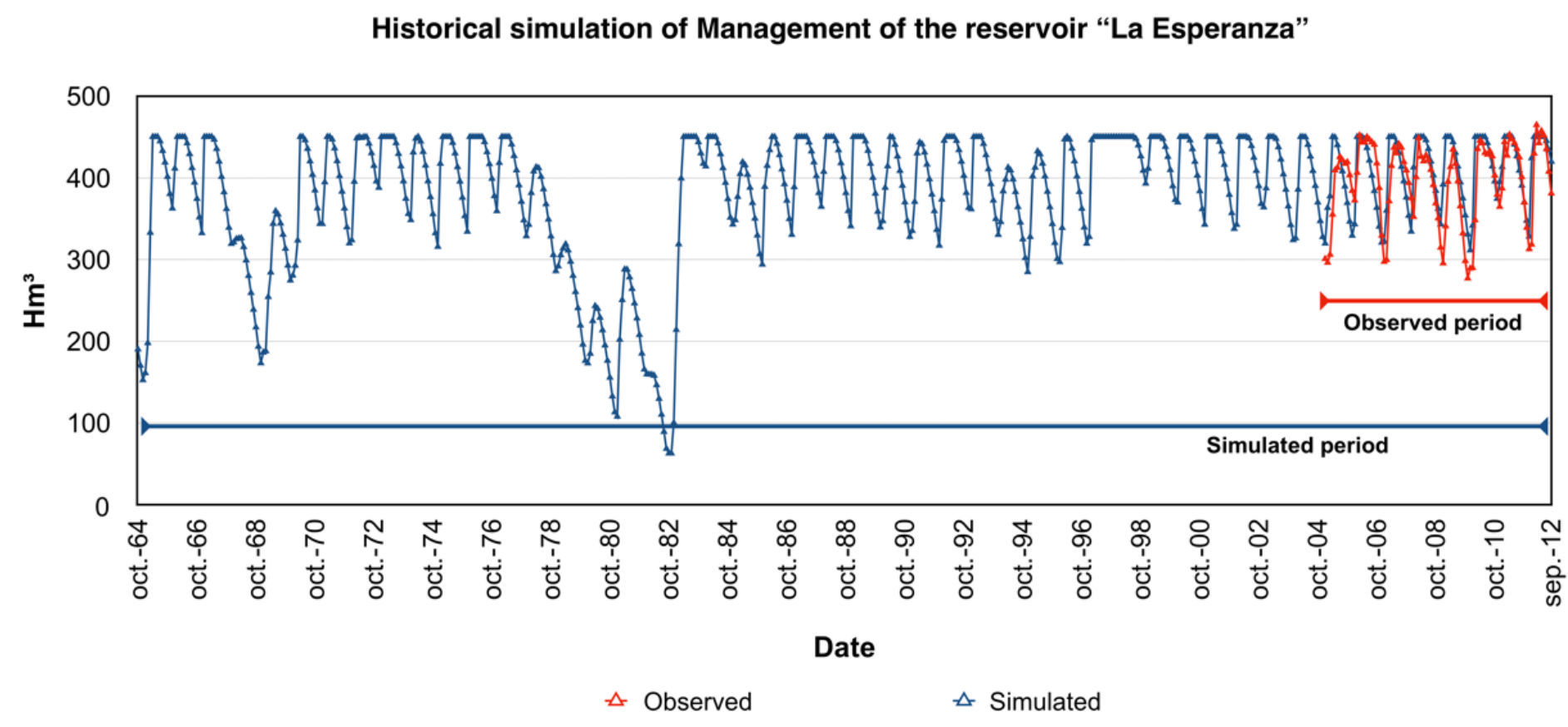

Fig. 5. Historical simulation of water level in the Esperanza reservoir of the Carrizal River exploitation system in the Chone River Basin. Current Irrigated area 7250 ha.

\subsection{CLIMATE CHANGE SCENARIOS AND BIAS CORRECTION}

To understand the precision in the projections and to correct biases in the 1964-2100 period, the data extracted from the global climate models were compared to the historical data of the 1961-1990 period. The comparison was made using climate data, comparing both GCM values with historical data and extracting a bias correction coefficient based on the differences.

The data extracted from the global climate models and described in the methodology are shown in Fig. 6. They correspond to the monthly temperature anomaly (Fig. 6a) and precipitation (Fig. 6b) for the three simulation periods. The details of such anomalies are presented below.

Under the RCP4.5 and RCP8.5 scenarios, the average maximum temperature by the middle of the $\mathrm{XXI}$ century has an upward trend in all months and varies from 0.9 to $2.5^{\circ} \mathrm{C}$ and 1 to $2.7^{\circ} \mathrm{C}$ in the CCSM4 and ECHAM6 models, respectively. The Intergovernmental Panel on Climate Change (IPCC, 2013) reported that the average global surface temperature shows a warming trend of $0.85{ }^{\circ} \mathrm{C}\left(0.65\right.$ to $\left.1.06{ }^{\circ} \mathrm{C}\right)$ during the 1880 to 2012 period. 
In essence, in the RCP4.5 scenario, the mean temperature could increase from 0.8 to $1.2^{\circ} \mathrm{C}(1.4$ to $1.8^{\circ} \mathrm{C} ; 1.5$ to $\left.2.1^{\circ} \mathrm{C}\right)$ and from 1 to $1.5^{\circ} \mathrm{C}\left(1.8\right.$ to $2.2^{\circ} \mathrm{C} ; 2$ to $\left.2.4^{\circ} \mathrm{C}\right)$ in the CCSM4 and ECHAM6 models, respectively, for the years 2010-39 (2040-69; 2070-99). In the RCP8.5 scenario, the average temperature could increase from 0.9 to $1.4^{\circ} \mathrm{C}\left(1.7\right.$ to $2.4{ }^{\circ} \mathrm{C} ; 2.7$ to $\left.3.8^{\circ} \mathrm{C}\right)$ and from 1.2 to $1.4{ }^{\circ} \mathrm{C}\left(2.4\right.$ to $2.8^{\circ} \mathrm{C}$; 3.6 to 4.2 ${ }^{\circ} \mathrm{C}$ ) for CCSM4 and ECHAM6, respectively, for the years 2010-39 (2040-69; 2070-99). It is likely that for the 2081-2100 period, the increase in the average global surface temperature is between $1.1^{\circ} \mathrm{C}$ to $2.6^{\circ} \mathrm{C}$ under RCP4.5 and between $2.6^{\circ} \mathrm{C}$ and $4.8^{\circ} \mathrm{C}$ for RCP 8.5 (IPCC, 2013b).

The future precipitation has uncertain changes, with a trend different from the temperature. According to CCSM4, precipitation increases (50 mm/month) and decreases (-60 mm/month) both in the dry and wet season, without showing significant changes in the RCP4.5 scenario for the years 2010-39, 204069, 2070-99. In contrast, in the RCP8.5 scenario for 2070-2099, precipitation increases in all months reaching $100 \mathrm{~mm} / \mathrm{month}$, decreasing only in October with values of $70 \mathrm{~mm} / \mathrm{month}$. In the remaining periods of the last scenario, the results are like those of the previous scenarios. In ECHAM6, precipitation will increase up to $60 \mathrm{~mm} / \mathrm{month}$ in the RCP4.5 and RCP8.5 scenarios, showing a decrease in certain months reaching levels down to $-30 \mathrm{~mm} / \mathrm{month}$ in the 2010-39, 2040-69 period. In the 2070-99 period, the model shows an increase of between 10 to $100 \mathrm{~mm} / \mathrm{month}$ and a decrease down to $-25 \mathrm{~mm} / \mathrm{month}$ from May to September in all scenarios, except for RCP4.5 where no decrease is shown.

Future rains indicate a change in precipitation patterns. In CCSM4, rains increase from November to February reaching $380 \mathrm{~mm}$ in February, and decrease from March to May, increasing again from June to September going from $10 \mathrm{~mm} / \mathrm{month}$ to $50 \mathrm{~mm} / \mathrm{month}$. ECHAM6 shows an increasing trend in rains in all months of the year, except for March, which indicates a decrease in the RCP8.5 scenario. The changes in temperature progressively intensify according to the periods and scenario, with the smallest and strongest significance in RCP4.5 and RCP8.5, respectively. The average temperature in the study area was $25.7^{\circ} \mathrm{C}$ during the wet season and $24.7^{\circ} \mathrm{C}$ in the dry season. With the estimated changes, average temperatures can reach values of up to $28.2^{\circ} \mathrm{C}$ y $27.2^{\circ} \mathrm{C}$ in the wet and dry season, respectively, for the end of the XXI century, according to the RCP4.5 scenario. 
Magrin et al., (2014) argue that a decrease in precipitations is projected for the north part of South America and an increase for North-western Ecuador. Additionally, future climate warming is expected in these areas. (Niang et al., 2014) estimate an increase in temperatures in Africa above the average global levels, although precipitation is expected to be less regular and unpredictable. Asia is more likely to have increased temperatures in upland areas by the middle of the XXI century, and in Eastern and Southern areas by the end of the XXI century. A warming scenario is also expected to occur (Hijioka et al., 2014).

a)
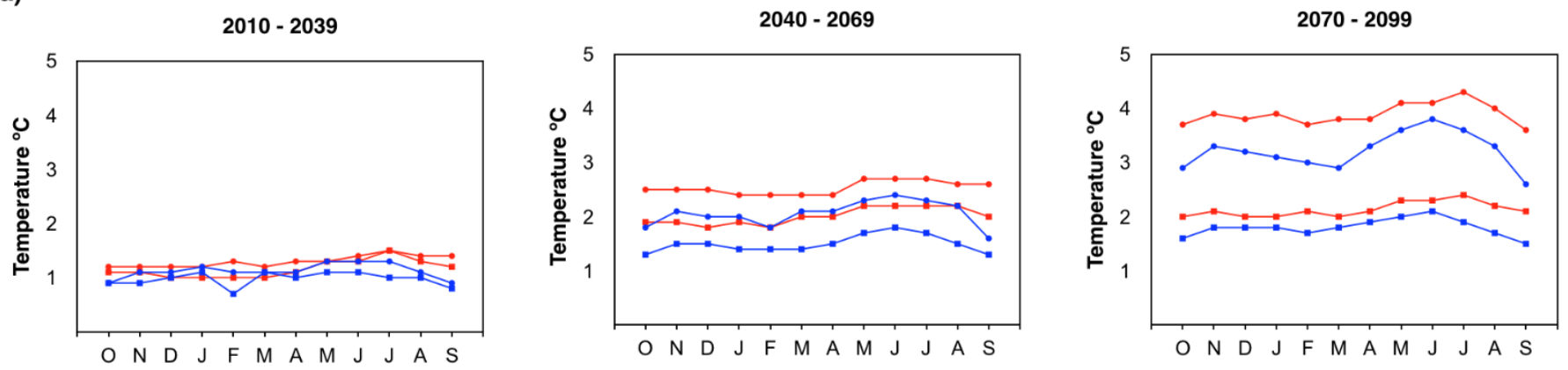

b)
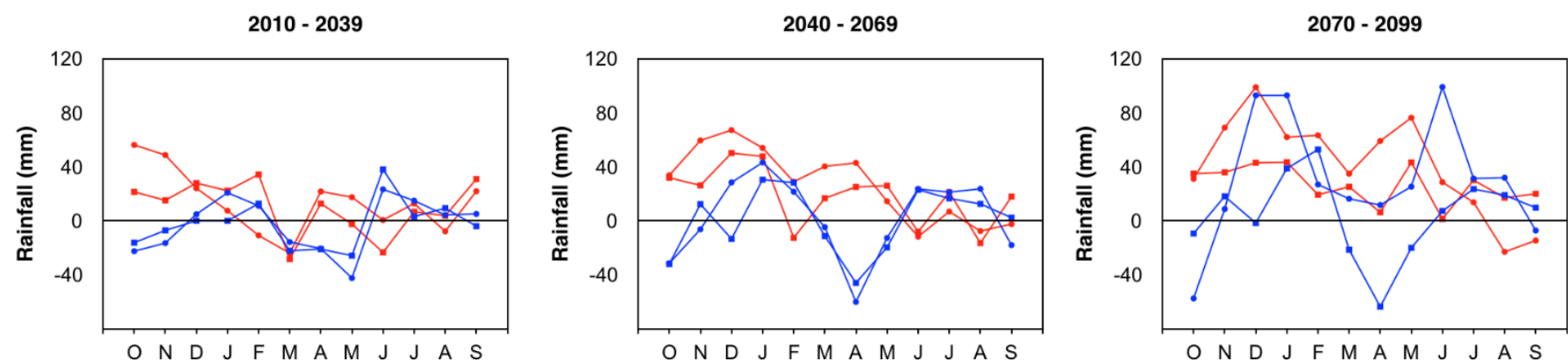

ㅁ CCSM4 - RCP 4.5

- $\operatorname{CCSM} 4$ - RCP 8.5

ㅁ. ECHAM6 - RCP 4.5

0. ECHAM6 - RCP 8.5

Fig. 6. Anomalies of; a) temperature; and b) precipitation, as extracted from the global climate models under the RCP4.5 and RCP8.5 scenarios, for the 2010-39, 2040-69, 2070-99 periods.

\subsection{CLIMATE CHANGE IMPACTS}

\subsubsection{Effects on evapotranspiration and crop water demand}

The increase in temperature has a significant impact on evaporation (EV) (Acharjee et al., 2017; Li et al., 2012; Tao et al., 2015) and potential evapotranspiration (PET) (Bates et al., 2008; Fu et al., 2009; Gharbia et al., 2018). The results from the CCSM4 predict a 5\% (PET Th) 2\% (PET P-M) increase in evapotranspiration in the 2010-39 period, 11\% (PET Th) 6\% (PET P-M) for 2040-69, and up to a 15\% (PET Th) 9\% (PET P-M) for (2070-99) in the RCP4.5 scenario. In the RCP8.5, an increase of 17\% and 50\% (PET Th) $10 \%$ and 36\% (PET P-M) is expected for 2040-69 and 2070-99, respectively. As for ECHAM6, the increase in precipitation is expected to be higher than the CCSM4 projections. Thus, in the RCP4.5 and 
RCP8.5 scenarios, an 18\% and 28\% (PET Th) 15\% and 25\% (PET P-M) increase are expected in the 201039 period. For the 2040-69, an increase of 32\% and 37\% (PET Th) 25\% and 27\% (PET P-M) are expected. An increase of 41\% and 61\% (PET Th) 33\% and 42\% (PET P-M) is expected by the long-term.

The CCSM4 results foresee a 12\% (PET Th) 3\% (PET P-M) increase in average annual potential evapotranspiration for 2010-39; 20\% (PET Th) 5\% (PET P-M) for 2040-69 and 25\% (PET Th) 6\% (PET PM) by the end of the century according to the RCP4.5 scenario. In contrast, in the RCP8.5 scenario, a 15\% (PET Th) 9\% (PET P-M) increase is expected for (2010-2039); and up to 54\% (PET Th) 10\% (PET P-M) for (2070-99). According to ECHAM6, average monthly potential evapotranspiration is expected to increase from $141.8 \mathrm{~mm} / \mathrm{month}$ (PET Th) $130 \mathrm{~mm} / \mathrm{month}$ (PET P-M) (RCP4.5) to $144 \mathrm{~mm} / \mathrm{month}$ (PET Th) 135 mm/month (PET P-M) (RCP8.5) for the 2010-39 period, which represents a 17\% (PET Th) 4\% (PET P-M) level above the control period. Monthly values of $158.5 \mathrm{~mm} / \mathrm{month}$ (PET Th) $133 \mathrm{~mm} / \mathrm{month}$ (PET P-M) (RCP4.5) and 170.8 mm/month (PET Th) 135 mm/month (PET P-M) (RCP8.5) are expected for the 204069 period. The values for the end of the century will be $161.8 \mathrm{~mm} / \mathrm{month}$ (PET Th) $134 \mathrm{~mm} / \mathrm{month}$ (PET PM) (RCP4.5) and $210.7 \mathrm{~mm} / \mathrm{month}$ (PET Th) $141 \mathrm{~mm} / \mathrm{month}$ (PET P-M) (RCP8.5). Fig. 9 shows the seasonal and annual changes in PET.

The results obtained with the simulations indicate a higher water requirement to satisfy potential evapotranspiration values. Maximum water demands of $75 \mathrm{~mm} / \mathrm{month}$ and $69 \mathrm{~mm} / \mathrm{month}$ are expected for the 2010-39 period. Levels up to $90 \mathrm{~mm} / \mathrm{month}$ and $88.5 \mathrm{~mm} / \mathrm{month}$ are predicted for the 2040-69 period, and $100 \mathrm{~mm} / \mathrm{month}$ and $114 \mathrm{~mm} / \mathrm{month}$ for 2070-99, in CSM4 and ECHAM6 respectively. These values range from $4 \%$ to $77 \%$ of the water requirements in the historical analysis, according to PET calculations by Thornthwaite method (see Table 2), while PET calculations by Penman-Monteith method show an increase until 4\% (see Table 3). Bates et al., (2008) point out that the variability in precipitation and the increase in temperatures could generate higher demand for irrigation water, even in the scenario where precipitation remains constant during the crop-growing season. 


\begin{tabular}{lccccc}
\hline \hline & \multicolumn{2}{c}{ Net demand } & \multicolumn{2}{c}{ Gross demand } & \\
\cline { 2 - 5 } Agricultural demand & $\begin{array}{c}\text { Current } \\
\text { demand } \\
\text { (7250 ha) }\end{array}$ & $\begin{array}{c}\text { Design } \\
\text { demand } \\
\text { (13268 ha) }\end{array}$ & $\begin{array}{c}\text { Current } \\
\text { demand } \\
\text { (7250 ha) }\end{array}$ & $\begin{array}{c}\text { Design } \\
\text { demand } \\
(\mathbf{1 3 2 6 8} \text { ha) }\end{array}$ & Increase \\
\hline Historic & 60.0 & 149.3 & 109.8 & 273.2 & -- \\
\hline Short term & & & & & \\
\hline CCSM4 RCP4.5 2010-39 & 70.2 & 174.7 & 128.5 & 319.7 & $17 \%$ \\
ECHAM6 RCP4.5 2010-39 & 66.0 & 164.2 & 120.8 & 300.6 & $10 \%$ \\
CCSM4 RCP8.5 2010-39 & 71.4 & 177.7 & 130.7 & 325.2 & $19 \%$ \\
ECHAM6 RCP8.5 2010-39 & 62.4 & 155.3 & 114.2 & 284.2 & $4 \%$ \\
\hline Medium term & & & & & \\
\hline CCSM4 RCP4.5 2040-69 & 75.0 & 186.6 & 137.3 & 341.5 & $25 \%$ \\
ECHAM6 RCP4.5 2040-69 & 73.8 & 183.6 & 135.1 & 336.1 & $23 \%$ \\
CCSM4 RCP8.5 2040-69 & 83.4 & 207.5 & 152.6 & 379.8 & $39 \%$ \\
ECHAM6 RCP8.5 2040-69 & 81.6 & 203.1 & 149.3 & 371.6 & $36 \%$ \\
\hline Long term & & & & & \\
\hline CCSM4 RCP4.5 2070-99 & 79.2 & 197.1 & 144.9 & 360.7 & $32 \%$ \\
ECHAM6 RCP4.5 2070-99 & 71.4 & 177.7 & 130.7 & 325.2 & $19 \%$ \\
CCSM4 RCP8.5 2070-99 & 92.4 & 229.9 & 169.1 & 420.8 & $54 \%$ \\
ECHAM6 RCP8.5 2070-99 & 106.2 & 264.3 & 194.4 & 483.6 & $77 \%$ \\
\hline \hline
\end{tabular}

Table 2. - Increase in net and gross agricultural demand in the study area, calculated for the historical (7,250 ha) and future (13,268 ha) monthly water demand from of future water requirements, using the PET of Thornthwaite method.

\begin{tabular}{|c|c|c|c|c|c|}
\hline \multirow[b]{2}{*}{ Agricultural demand } & \multicolumn{2}{|c|}{ Net demand } & \multicolumn{2}{|c|}{ Gross demand } & \multirow[b]{2}{*}{$\begin{array}{l}\text { Water } \\
\text { requirement } \\
\text { Increase }\end{array}$} \\
\hline & $\begin{array}{c}\text { Current } \\
\text { demand } \\
(7250 \mathrm{ha})\end{array}$ & $\begin{array}{c}\text { Design } \\
\text { demand } \\
(13268 \mathrm{ha})\end{array}$ & $\begin{array}{c}\text { Current } \\
\text { demand } \\
\text { (7250 ha) }\end{array}$ & $\begin{array}{c}\text { Design } \\
\text { demand } \\
(13268 \mathrm{ha})\end{array}$ & \\
\hline Historic & 60.0 & 149.3 & 109.8 & 273.2 & -- \\
\hline \multicolumn{6}{|l|}{ Short term } \\
\hline CCSM4 RCP4.5 2010-39 & 62.4 & 114.2 & 155.3 & 284.2 & $4 \%$ \\
\hline ECHAM6 RCP4.5 2010-39 & 57.0 & 104.3 & 141.8 & 259.6 & $-5 \%$ \\
\hline CCSM4 RCP8.5 2010-39 & 62.4 & 114.2 & 155.3 & 284.2 & $4 \%$ \\
\hline ECHAM6 RCP8.5 2010-39 & 52.8 & 96.6 & 131.4 & 240.5 & $-12 \%$ \\
\hline \multicolumn{6}{|l|}{ Medium term } \\
\hline CCSM4 RCP4.5 2040-69 & 62.4 & 114.2 & 155.3 & 284.2 & $4 \%$ \\
\hline ECHAM6 RCP4.5 2040-69 & 55.2 & 101.0 & 137.4 & 251.4 & $-8 \%$ \\
\hline CCSM4 RCP8.5 2040-69 & 62.4 & 114.2 & 155.3 & 284.2 & $4 \%$ \\
\hline ECHAM6 RCP8.5 2040-69 & 55.8 & 102.1 & 138.9 & 254.1 & $-7 \%$ \\
\hline \multicolumn{6}{|l|}{ Long term } \\
\hline CCSM4 RCP4.5 2070-99 & 61.8 & 113.1 & 153.8 & 281.4 & $3 \%$ \\
\hline ECHAM6 RCP4.5 2070-99 & 54.0 & 98.8 & 134.4 & 245.9 & $-10 \%$ \\
\hline CCSM4 RCP8.5 2070-99 & 51.6 & 94.4 & 128.4 & 235.0 & $-14 \%$ \\
\hline ECHAM6 RCP8.5 2070-99 & 53.4 & 97.7 & 132.9 & 243.2 & $-11 \%$ \\
\hline
\end{tabular}

Table 3. - Increase in net and gross agricultural demand in the study area, calculated for the historical (7,250 ha) and future (13,268 ha) monthly water demand from of future water requirements, using the PET of Penman-Monteith method. 
The highest water demand in our study is expected during the dry season when ETP values are significant, and soil moisture is shallow. Demand is also high during the first wet months due to the minimal increase in precipitation and high-temperature levels (Fig. 7). Due to climate change Alcamo et al., (2007) indicate that, in most developing regions, water stress will increase; however, in most industrialised regions, it will descend. Fischer et al., (2007) claim that, in developing regions net irrigation requirements increase by over $50 \%$ and in developed regions by $16 \%$. Gondim et al., (2012) projected that irrigation water demand would increase by $8 \%-9 \%$ by the middle of the XXI century in a Brazilian river basin. Savé et al., (2012) determined the irrigation demand would increase by 40-250\%, depending on crops (maize, apple and alfalfa) by the end of the XXI century in a Spanish River basin. Nkomozepi and Chung, (2012) mention that although there is significant uncertainty in the projections, it is expected that irrigation water demand for maize crops will increase by 66\% in the 2050s and 99\% in the 2090s in Zimbabwe. Likewise, irrigation demand for rice crops in Korea will increase by $2.4 \%$ y $7.9 \%$ in the in the 2050s and 99\% in the 2090s, respectively (Chung and Nkomozepi, 2012).
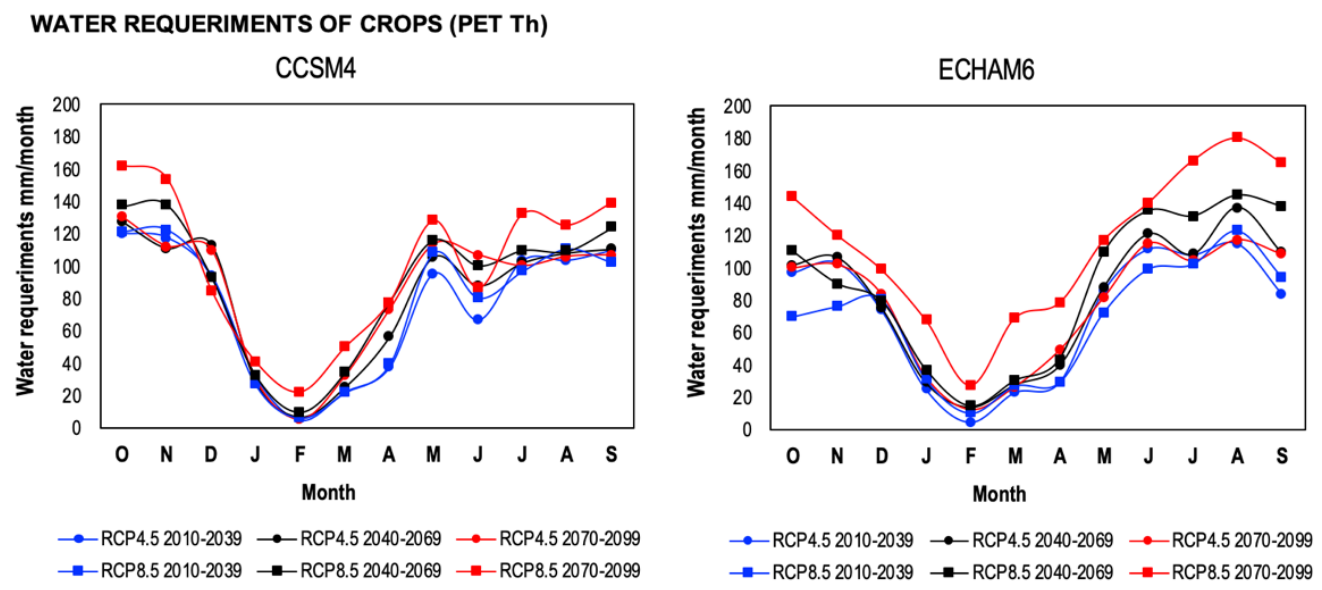

WATER REQUERIMENTS OF CROPS (PET P-M)
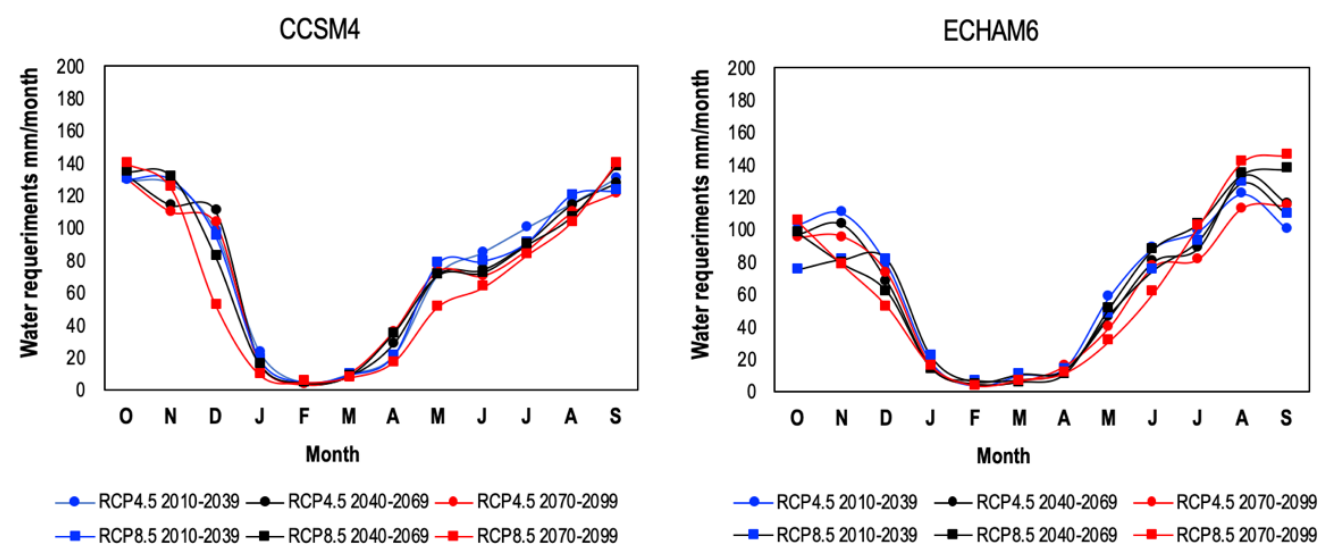

Fig. 7. Monthly water demand for future crops under climate change scenarios. 


\subsubsection{Impact on water resources}

Changes on hydrological variables are reflected in the changes in basin contribution during the hydrological year. The CCSM4 simulation shows that precipitation in the wet season will decrease by approximately 4\%. The most significant decrease was registered in the RCP4.5 scenario in the 2010-39 period, with monthly average precipitation of $206.64 \mathrm{~mm}$, representing $9 \mathrm{~mm}$ below the control period. The opposite happens during the dry season, with positive values above $20 \%$ and below $50 \%$. The average monthly precipitation will increase from $6 \mathrm{~mm}$ to $12 \mathrm{~mm}$ every month. The ECHAM6 simulation indicates that precipitation will increase in both stations: up to $30 \%$ in the wet season and by $40 \%-94 \%$ in the dry season, with values from $35 \mathrm{~mm} / \mathrm{month}$ to $48 \mathrm{~mm} / \mathrm{month}$. The future annual changes in the hydrological variables can be observed in Fig. 8.

a)
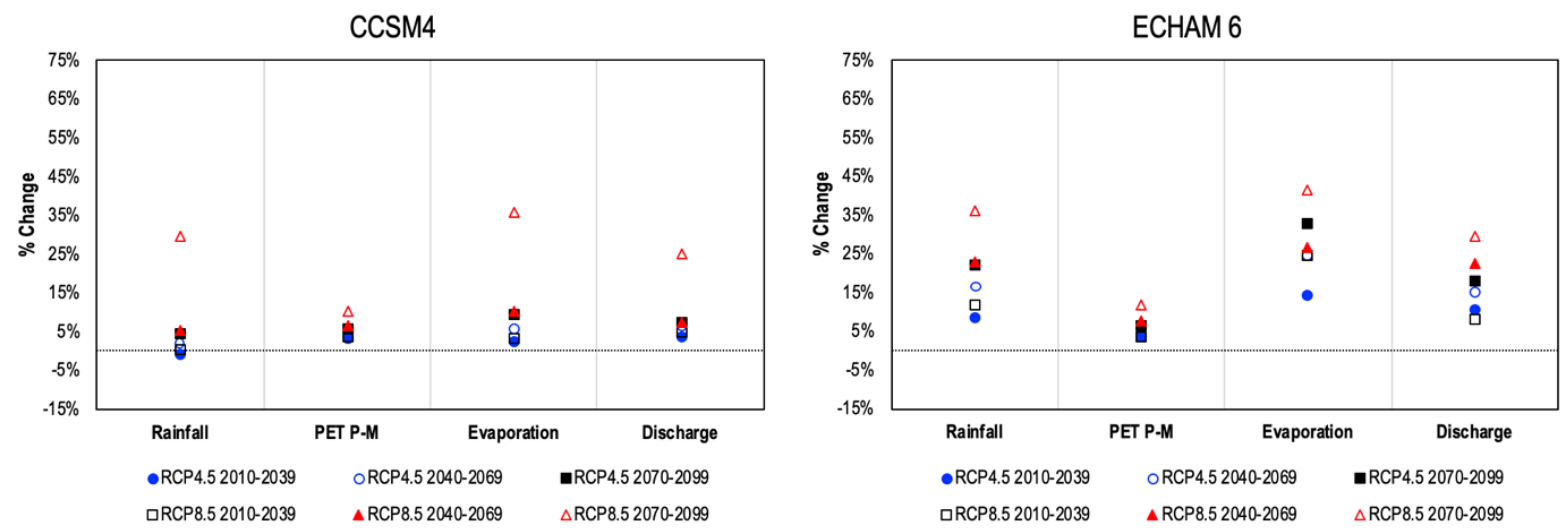

b)
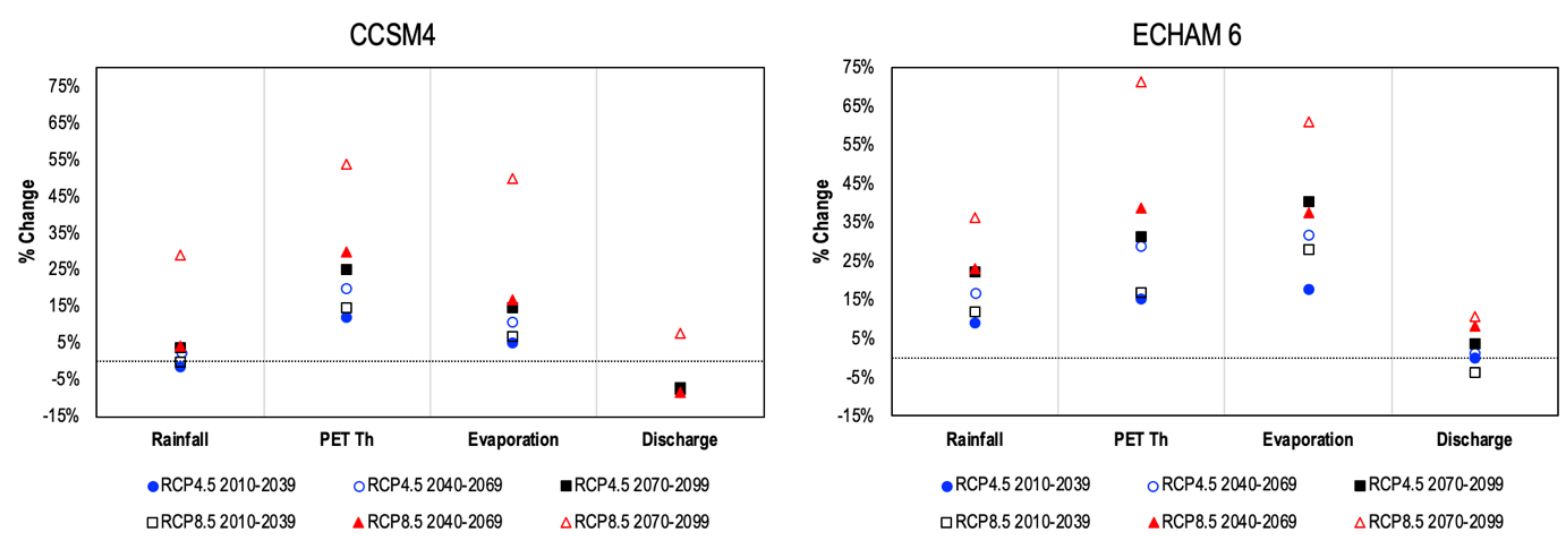

Fig. 8. Future annual changes in the hydrological variables of the study area; a) hydrological balance using the PET formulation by the Penman-Monteith method; b) hydrological balance using the PET formulation by the Thornthwaite method

Both models show similar increases in precipitation in the dry season, which confirms a change in historical precipitation patterns. (IPCC, 2007b) point out that in the RCP8.5 scenario, there will be an 
increase in average annual precipitation in high latitudes and the Equatorial Pacific Ocean, but a decrease is projected in a high number of dry zones in subtropical and mid-latitudinal regions.

Results show that runoff depends on the extent of the increase of precipitation, although not always the case, for instance, Lindström and Bergström, (2004). CCSM4 simulations show decreasing levels of 4\% and $6 \%$ in surface runoff in all scenarios and periods due to the increase in temperature and minimal increase in precipitation. Runoff volume reached $36.8 \mathrm{~mm} / \mathrm{month}$ and $37.7 \mathrm{~mm} / \mathrm{month}$ in the RCP4.5 scenario for the 2010-39 and 2070-99, respectively. ECHAM6 simulation shows a 7\% decrease in surface runoff in the 201039 period using the RCP8.5 scenario. In the $2040-69$ period, it will increase by $3 \%$, and it is expected to increase by $6 \%$ by the end of the century, which represents a runoff level of $42.9 \mathrm{~mm} / \mathrm{month}$. The increase in runoff is most significant in February and March when the area records the highest precipitation levels. In contrast, there is a decrease in runoff during the months of the dry season.

Similar results were obtained for infiltration due to the increase in temperature and minimal increase in precipitation. The variable registers a nonsignificant reduction in all scenarios and periods of the CCSM4 model, except for the RCP8.5 scenario at the end of the century, with an increase of up to 18\%. ECHAM6 shows an increase in infiltration of $2 \%$ and $9 \%$ for the RCP4.5 scenario, and between $4 \%$ and $21 \%$ for the RCP8.5 scenario.

Contribution to the fluvial network depends not only on precipitation but also on the behaviour of all hydrological variables. Kundzewicz et al., (2007) argue that precipitation, temperature and evaporative demand are the main climate factors that determine water availability. In this study, we can observe that, using PET values obtained by Penman- Monteith method an increase in contribution to the fluvial network is registered in all simulations performed, while that, using values obtained by Modified Thornthwaite method, despite the increase in precipitation during the dry season, a reduction in contribution to the fluvial network is registered in the CCSM4 simulation for all periods and scenarios during the dry and wet seasons. RCP8.5 scenario was the only exception, and an increase in flow can be observed for the two seasons of the 2070-99 period. The observed reductions do not exceed 12\% concerning the control period, representing a 
maximum reduction of $7 \mathrm{hm}^{3}$ for the wet season and $1 \mathrm{hm}^{3}$ for the dry season. The results from the ECHAM6 simulation indicate that an increase is expected for the wet season, except for the RCP8.5 scenario in the 2010-39 period. The highest increase $\left(6.3 \mathrm{hm}^{3}\right)$ during the wet season can be observed for the 2070-2099 period under the RCP8.5 scenario. In the dry season, it is expected that contribution increases by a maximum level of $14 \%\left(1 \mathrm{hm}^{3}\right)$ concerning historical contribution in the control period. As a result, average monthly contributions of $53 \mathrm{hm}^{3}$ and $60 \mathrm{hm}^{3}$ are predicted for the wet season, and $9 \mathrm{hm}^{3}$ and $11 \mathrm{hm}^{3}$ for the dry season in both basins. This seasonal variation is shown in Fig. 9.

(Gebrechorkos et al., 2019) studied the impacts of projected change in climate on water balance in basins of Ethiopia (EthShed), Kenya (KenShed), and Tanzania (TanShed). The results show an increase in precipitation, relative to the baseline period (1961-1990), in EthShed (14\% - 50\%) and KenShed (15\% 86\%) and a decrease in TanShed (1.3\% - 6.3\%) in the 20s (2011-2040), 50s (2041-2070), and 80s (20712100) under the three Representative Concentration Pathways (RCPs; RCP2.6, RCP4.5, and RCP8.5). maximum temperature (anomalies up to $3.7^{\circ} \mathrm{C}$ ) and minimum temperature (anomalies up to $2.76{ }^{\circ} \mathrm{C}$ ) will be warmer than the baseline period throughout the 21 century in all three basins. An increase (decrease) in seasonal and annual streamflow, soil-water, and evaporation in EthShed and KenShed (TanShed) is projected in the 20s, 50s, and 80s.

The results show that, PET calculations by Penman Monteith and Thornthwaite methods show similar results under the current climate. However, under climate change, Thornthwaite method gives results significantly higher regarding to Penman Monteith method. Some research claim that, Thornthwaite approach underestimate PET under arid conditions (Hashemi and Habibian, 1979; Malek, 1987; Pelton et al., 1960), and to overestimate in the super humid climate and near locations to large bodies of water found in the lowlands of the Amazon region (Camargo et al., 1999). However, Camargo et al., (1999) also claim that, Thornthwaite equation for estimating the PET worked very well in humid regions, even with a moderate dry season, giving very close estimates to those obtained by the Penman-Monteith method. Also, according to Yang et al., (2017) the contribution of PET changes to the variations in global and continental drylands gradually enhanced with global warming, and the Thornthwaite method was found to be increasingly less applicable under climate change. 
The results in this study also show that, the water requirements for crops will increase around $4 \%$ and $45 \%$ due climate change. Other researches claim that under effect of climate change the irrigation water requirements will increase in tropical areas e.g., (Knox et al., 2010) have assessed the spatial and temporal impacts of climate change on irrigation water requirements and yield for sugarcane grown in Swaziland. The results showed that, to produce a unit weight of sucrose equivalent to current optimum levels of production, future irrigation needs were predicted to increase by $20-22 \%$, and that, that with climate change, the current peak capacity of existing irrigation schemes could fail to meet the predicted increases in irrigation demand in nearly $50 \%$ of years assuming unconstrained water availability. De Silva et al., (2007) claim that, across most of Sri Lanka, the impacts of climate change will increase wet season (Maha) paddy irrigation requirements in the scenarios considered and that paddy cultivation will become more water stressed. The global analysis of the impact of climate change and climate variability on irrigation water requirements shows that, the global total of net irrigation water requirements is computed to increase by $3-5 \%$ until the 2020s and by 5-8\% until the 2070s (Döll, 2002). The climate change does not only affect water resources but also water demand. Future water and food security will depend, among other factors, on the impact of climate change on water demand for irrigation. Therefore, given that the demands calculation is based in the evapotranspiration potential, is recommended to use the Penman-Monteith method to the demand calculation. 

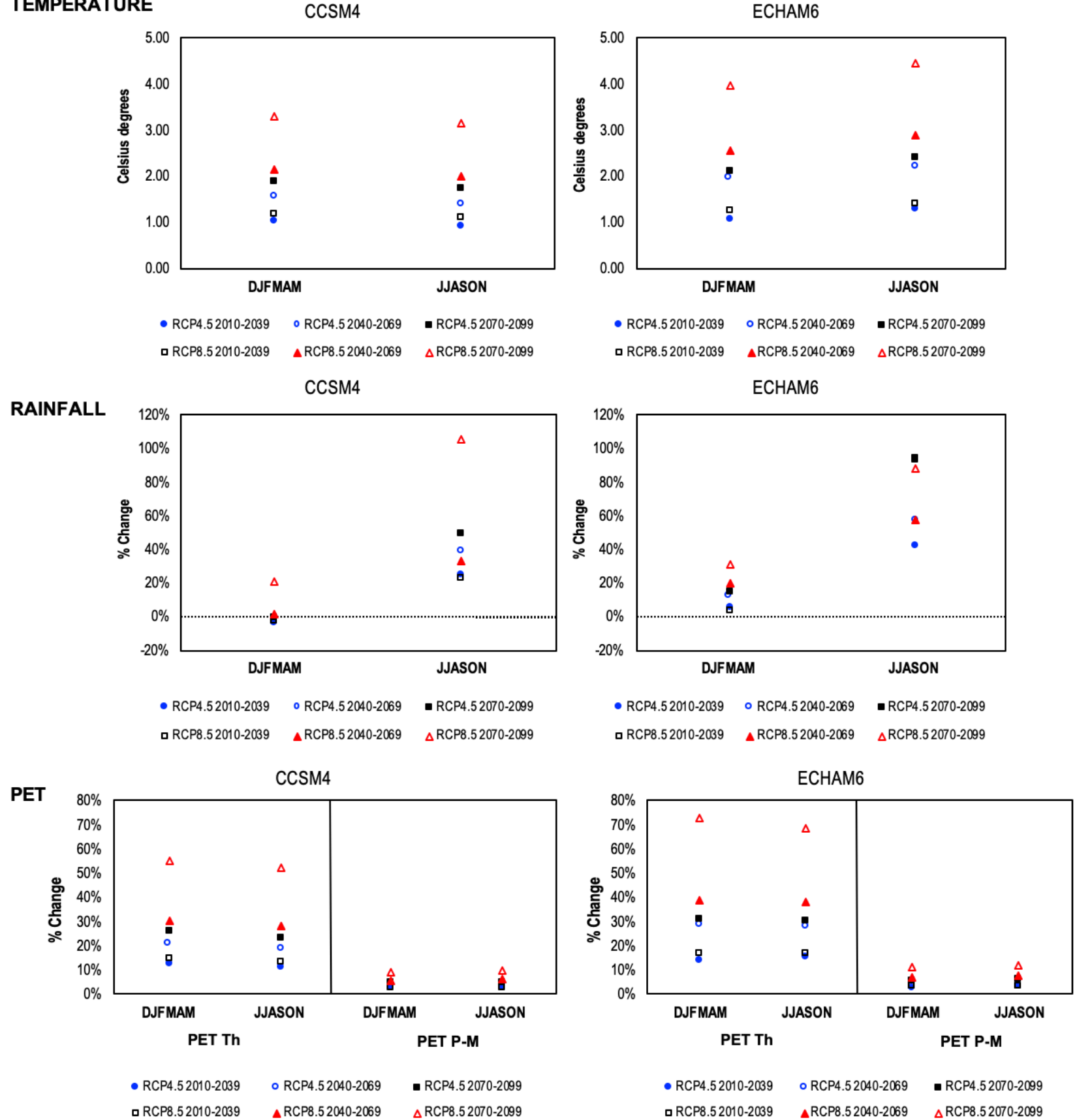

DISCHARGE

CCSM4
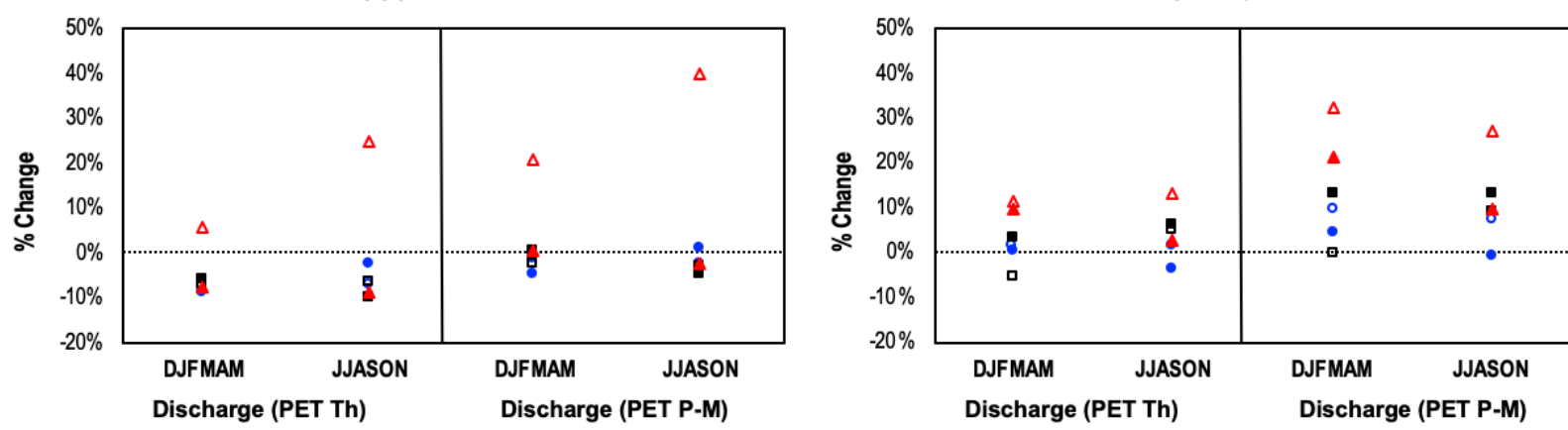

$\begin{array}{lll}-\mathrm{RCP} 4.52010-2039 & \circ \mathrm{RCP} 4.52040-2069 & \text { - RCP4.52070-2099 } \\ \text { 口 RCP8.5 2010-2039 } & \Delta \mathrm{RCP} 8.52040-2069 & \Delta \mathrm{RCP} 8.52070-2099\end{array}$

- RCP4.5 2010-2039 ० RCP4.5 2040-2069 - RCP4.5 2070-2099 口RCP8.5 2010-2039 $\triangle R C P 8.52040-2069 \quad \triangle R C P 8.52070-2099$

Fig. 9. Future seasonal changes in temperature, precipitation, PET (Thornthwaite and Penman-Monteith methods) and simulated flow in the study area. 
(Bhatta et al., 2019b) studied the climate change impact on the hydrology of the Himalayan River Basin, the results show an increase in the annual average maximum temperature $\left(+4{ }^{\circ} \mathrm{C}\right)$ and minimum temperature $\left(+5.5^{\circ} \mathrm{C}\right)$, and a decrease in precipitation $(-4.5 \%)$ is projected by the end of the twenty-first century under RCP8.5 scenarios. The study found that the future climate could decrease the streamflow by over $8.5 \%$ during the twenty-first century under RCP8.5 scenarios.

The results demonstrate that the variation in temperature is an essential factor for quantifying contribution in a river basin because if the increase in precipitation is not representative and distributed along the hydrological year, the balance will become negative for that particular year. This can be evidenced in the results from the CCSM4 simulation, which indicate that changes in precipitation are negative during the wet season (decrease) and positive during the dry season (increase). However, the increase in temperature resulted in negative values (decrease) in contributions for all periods and scenarios, except for the RCP8.5 simulation in the 2070-99 period, which shows an increase in contribution due to the significant increase in precipitation (Fig. 9). The ECHAM6 simulation shows a progressive increase with the three scenarios. The results indicate that it is possible that basin contribution will see an increase as a result of a significant increase in temperature and precipitation. IPCC, (2014) expects that, for each degree Celsius that global temperatures increases, at least $20 \%$ of water supply will be reduced in arid and semiarid regions in subtropical and mid-latitudinal latitudes, and González-Zeas et al., (2019), claim that in tropical mountainous areas the water demand is increasing rapidly.

\subsection{Current and future water resources management under climate change}

\subsubsection{Water resources system assessment under climate change}

Climate change affects the functionality and operation of the existing hydrological structure and water management practices (Kundzewicz et al., 2007), therefore, should be considered in the design and planning of water resources systems. Water management is an option to ensure adequate preparedness for water scarcity (Magrin et al., 2014) through reservoir operation rules (Ahmadi et al., 2015). The design curves or an irrigation efficiency can be used as an easy and reliable tool for o mitigate the impacts of climate change (Guo and Shen, 2016; Zhang et al., 2019). 
We performed a simulation of the functioning of water resources system with current and future demands under the effect of climate change considering the PET Th to verify the met of guarantees criteria and establish the adaptative operational measures.

With the short-term demands: UD $30 \mathrm{hm}^{3}$, Qec $15 \mathrm{hm}^{3}$, and $\mathrm{AD}$ (according model and scenario established in Table 2), the system met the monthly guarantee for the UD in all periods and can to expands by until 24,000 ha. Under the effect of climate change the simulation shows that, the UD meets monthly guarantee criteria but does not meet UTAH 10 criteria in any model, scenario and period, except in the model ECHAM6 to short term, while AD does not meet guarantee criteria in any simulation (Table 4 a). To solve it, it is established a reservation curve to the UD, that varies from 90 to $120 \mathrm{hm}^{3}$ until the end of the century (Table 4 b); a 0.43 irrigation efficiency, and two operation rules to the AD based on CCSM4 model 1) 25\% supply restriction 2) 50\% supply restriction. Is established to 25\% supply restriction when the reservoir level achieves $200 \mathrm{hm}^{3}$, and a 50\% supply restriction when it achieves $170 \mathrm{hm}^{3}$ (Table $4 \mathrm{c}$ ). With the measures established, the system is met with GM and UTAH 1 and 2 criteria but, they are not enough to meet to the long term. To make the system work is established to improve the irrigation efficiency from 0.43 to 0.58 (Table 4 d); However, this measure not ensure the supplying to the AD (UTAH 10) to meet with all guarantee criteria, it is necessary achieve an irrigation efficiency from 0.43 to 0.65 and to restrict the supplying up until 10\%. (Table 4 e). We indicate that, the met of guarantee criteria does not ensure continuous supply of agricultural demand. The simulations have been performed with prioritization of urban and environmental demand in all scenarios and periods; thus, agricultural demand will be affected by water scarcity. It is, therefore, necessary to use reservation curves to satisfy the urban demands and curves to ration the agricultural demands. The operating measures applied in the simulations are shown in Table 5. 


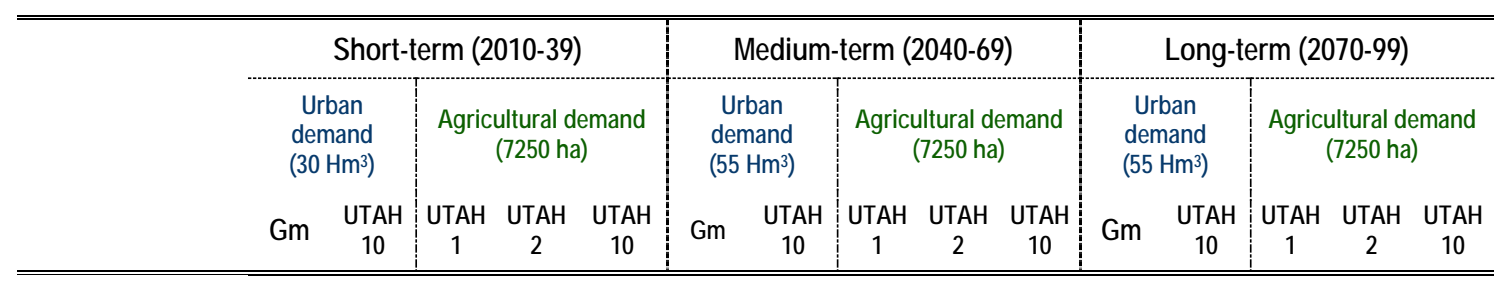

a)

Future simulation with effect of climate change (CC)

\begin{tabular}{|l|r|r|r|r|r|r|r|r|r|r|r|r|r|r|r|}
\hline CCSM4 RCP4.5 & $98 \%$ & $59 \%$ & $51 \%$ & $90 \%$ & $116 \%$ & $98 \%$ & $91 \%$ & $70 \%$ & $109 \%$ & $181 \%$ & $97 \%$ & $105 \%$ & $69 \%$ & $107 \%$ & $190 \%$ \\
\hline ECHAM6 RCP4.5 & $100 \%$ & $0 \%$ & $18 \%$ & $21 \%$ & $21 \%$ & $99 \%$ & $41 \%$ & $55 \%$ & $91 \%$ & $123 \%$ & $99 \%$ & $32 \%$ & $45 \%$ & $72 \%$ & $91 \%$ \\
\hline CCSM4 RCP8.5 & $99 \%$ & $58 \%$ & $49 \%$ & $87 \%$ & $112 \%$ & $97 \%$ & $116 \%$ & $80 \%$ & $117 \%$ & $218 \%$ & $99 \%$ & $48 \%$ & $58 \%$ & $93 \%$ & $153 \%$ \\
\hline ECHAM6 RCP8.5 & $100 \%$ & $8 \%$ & $12 \%$ & $21 \%$ & $21 \%$ & $99 \%$ & $30 \%$ & $40 \%$ & $76 \%$ & $97 \%$ & $98 \%$ & $43 \%$ & $61 \%$ & $95 \%$ & $173 \%$ \\
\hline
\end{tabular}

b)

CC + Management reservoir for Urban Demand (MUD)

\begin{tabular}{|c|c|c|c|c|c|c|c|c|c|c|c|c|c|c|c|}
\hline CCSM4 RCP4.5 & $100 \%$ & $0 \%$ & $55 \%$ & $95 \%$ & $132 \%$ & $100 \%$ & $0 \%$ & $87 \%$ & $126 \%$ & $217 \%$ & $100 \%$ & $0 \%$ & $76 \%$ & $115 \%$ & $227 \%$ \\
\hline ECHAM6 RCP4.5 & $100 \%$ & $0 \%$ & $18 \%$ & $21 \%$ & $21 \%$ & $100 \%$ & $0 \%$ & $58 \%$ & $97 \%$ & $145 \%$ & $100 \%$ & $0 \%$ & $51 \%$ & $91 \%$ & $16 \%$ \\
\hline CSM4 RCP8. & $100 \%$ & $0 \%$ & $51 \%$ & $91 \%$ & $128 \%$ & $100 \%$ & $0 \%$ & $87 \%$ & $126 \%$ & $258 \%$ & $100 \%$ & $0 \%$ & $62 \%$ & $101 \%$ & ( \\
\hline HAM6 RCP8.5 & $100 \%$ & $0 \%$ & $23 \%$ & $23 \%$ & $23 \%$ & $100 \%$ & $0 \%$ & $41 \%$ & $80 \%$ & $106 \%$ & $100 \%$ & $0 \%$ & $55 \%$ & $94 \%$ & 193 \\
\hline
\end{tabular}

c)

CC +MUD + Management reservoir for Agricultural Demand (MAD)

\begin{tabular}{|l|l|l|l|l|l|l|l|l|l|l|l|l|l|l|l|}
\hline CCSM4 RCP4.5 & $100 \%$ & $0 \%$ & $47 \%$ & $71 \%$ & $136 \%$ & $100 \%$ & $0 \%$ & $50 \%$ & $100 \%$ & $261 \%$ & $100 \%$ & $0 \%$ & $50 \%$ & $100 \%$ & $285 \%$ \\
\hline ECHAM6 RCP4.5 & $100 \%$ & $0 \%$ & $18 \%$ & $21 \%$ & $21 \%$ & $100 \%$ & $0 \%$ & $47 \%$ & $71 \%$ & $148 \%$ & $100 \%$ & $0 \%$ & $44 \%$ & $68 \%$ & $122 \%$ \\
\hline CCSM4 RCP8.5 & $100 \%$ & $0 \%$ & $47 \%$ & $71 \%$ & $133 \%$ & $100 \%$ & $0 \%$ & $71 \%$ & $128 \%$ & $282 \%$ & $100 \%$ & $0 \%$ & $50 \%$ & $83 \%$ & $186 \%$ \\
\hline ECHAM6 RCP8.5 & $100 \%$ & $0 \%$ & $23 \%$ & $23 \%$ & $23 \%$ & $100 \%$ & $0 \%$ & $47 \%$ & $67 \%$ & $142 \%$ & $100 \%$ & $0 \%$ & $50 \%$ & $91 \%$ & $212 \%$ \\
\hline
\end{tabular}

d)

$C C+M U D+M A D+$ Improving irrigation efficiency to 0.58

\begin{tabular}{|l|r|r|r|r|r|r|r|r|r|r|r|r|r|r|r|r|}
\hline CCSM4 RCP4.5 & $100 \%$ & $0 \%$ & $0 \%$ & $0 \%$ & $0 \%$ & $100 \%$ & $0 \%$ & $45 \%$ & $72 \%$ & $99 \%$ & $100 \%$ & $0 \%$ & $46 \%$ & $75 \%$ & $117 \%$ \\
\hline ECHAM6 RCP4.5 & $100 \%$ & $0 \%$ & $0 \%$ & $0 \%$ & $0 \%$ & $100 \%$ & $0 \%$ & $0 \%$ & $0 \%$ & $0 \%$ & $100 \%$ & $0 \%$ & $0 \%$ & $0 \%$ & $0 \%$ \\
\hline CCSM4 RCP8.5 & $100 \%$ & $0 \%$ & $0 \%$ & $0 \%$ & $0 \%$ & $100 \%$ & $0 \%$ & $40 \%$ & $74 \%$ & $167 \%$ & $100 \%$ & $0 \%$ & $26 \%$ & $37 \%$ & $37 \%$ \\
\hline ECHAM6 RCP8.5 & $100 \%$ & $0 \%$ & $0 \%$ & $0 \%$ & $0 \%$ & $100 \%$ & $0 \%$ & $0 \%$ & $0 \%$ & $0 \%$ & $100 \%$ & $0 \%$ & $26 \%$ & $49 \%$ & $71 \%$ \\
\hline
\end{tabular}

e)

$C C+M U D+M A D+$ Improving irrigation efficiency to 0.65

\begin{tabular}{|l|r|r|r|r|r|r|r|r|r|r|r|r|r|r|r|r|}
\hline CCSM4 RCP4.5 & $100 \%$ & $0 \%$ & $0 \%$ & $0 \%$ & $0 \%$ & $100 \%$ & $0 \%$ & $26 \%$ & $49 \%$ & $49 \%$ & $100 \%$ & $0 \%$ & $34 \%$ & $60 \%$ & $63 \%$ \\
\hline ECHAM6 RCP4.5 & $100 \%$ & $0 \%$ & $0 \%$ & $0 \%$ & $0 \%$ & $100 \%$ & $0 \%$ & $0 \%$ & $0 \%$ & $0 \%$ & $100 \%$ & $0 \%$ & $0 \%$ & $0 \%$ & $0 \%$ \\
\hline CCSM4 RCP8.5 & $100 \%$ & $0 \%$ & $0 \%$ & $0 \%$ & $0 \%$ & $100 \%$ & $0 \%$ & $47 \%$ & $74 \%$ & $96 \%$ & $100 \%$ & $0 \%$ & $0 \%$ & $0 \%$ & $0 \%$ \\
\hline ECHAM6 RCP8.5 & $100 \%$ & $0 \%$ & $0 \%$ & $0 \%$ & $0 \%$ & $100 \%$ & $0 \%$ & $0 \%$ & $0 \%$ & $0 \%$ & $100 \%$ & $0 \%$ & $13 \%$ & $13 \%$ & $13 \%$ \\
\hline
\end{tabular}

Table 4.- Assessment of the guarantee criteria meeting for supplying of demands under climate change context. The values indicate that the guarantee criteria are met (green) or that they are not met (orange). 


\begin{tabular}{|c|c|c|c|c|c|c|c|c|c|}
\hline \multirow{2}{*}{$\begin{array}{l}\text { Climate change } \\
\text { scenario }\end{array}$} & \multirow{2}{*}{$\begin{array}{c}\text { Dead } \\
\text { volume } \\
\left(\mathrm{hm}^{3}\right)\end{array}$} & \multirow{2}{*}{$\begin{array}{l}\text { Urban } \\
\text { Demand } \\
\left(\mathrm{hm}^{3}\right)\end{array}$} & \multirow{2}{*}{$\begin{array}{c}\text { Agricultural } \\
\text { demand } \\
\text { gross for } \\
7250 \mathrm{ha} \\
\left(\mathrm{hm}^{3}\right)\end{array}$} & \multirow{2}{*}{$\begin{array}{l}\text { Reservation } \\
\text { curve for } \\
\text { Urban } \\
\text { demand }\left(\mathrm{hm}^{3}\right)\end{array}$} & \multicolumn{2}{|c|}{$\begin{array}{l}\text { Preventive restriction of } \\
\text { agricultural demand }\end{array}$} & \multicolumn{2}{|c|}{$\begin{array}{c}\text { Definitive restriction of } \\
\text { agricultural demand }\end{array}$} & \multirow{2}{*}{$\begin{array}{l}\text { Irrigation } \\
\text { efficiency }\end{array}$} \\
\hline & & & & & $\begin{array}{l}\text { Reservoir } \\
\text { Level }\left(\mathrm{hm}^{3}\right)\end{array}$ & Restriction & $\begin{array}{l}\text { Reservoir } \\
\text { Level }\left(\mathrm{hm}^{3}\right)\end{array}$ & Restriction & \\
\hline \multicolumn{10}{|c|}{ Short-term (2010-39) } \\
\hline CCSM4 RCP4.5 & 70 & 30 & 174.7 & 85 & 200 & 0.25 & 170 & 0.5 & \multirow{4}{*}{0.43} \\
\hline ECHAM6 RCP4.5 & 70 & 30 & 164.2 & 70 & - & - & - & - & \\
\hline CCSM4 RCP8.5 & 70 & 30 & 177.7 & 90 & 200 & 0.75 & 170 & 0.5 & \\
\hline ECHAM6 RCP8.5 & 70 & 30 & 155.3 & 90 & - & - & - & - & \\
\hline \multicolumn{10}{|c|}{ Medium-term (2040-69) } \\
\hline CCSM4 RCP4.5 & 75 & 55 & 186.6 & 100 & 300 & 0.75 & 270 & 0.5 & \multirow{4}{*}{0.43} \\
\hline ECHAM6 RCP4.5 & 75 & 55 & 183.6 & 95 & 215 & 0.75 & 185 & 0.5 & \\
\hline CCSM4 RCP8.5 & 75 & 55 & 207.5 & 100 & 240 & 0.75 & 210 & 0.5 & \\
\hline ECHAM6 RCP8.5 & 75 & 55 & 203.1 & 95 & 250 & 0.75 & 220 & 0.5 & \\
\hline \multicolumn{10}{|c|}{ Long-term (2070-99) } \\
\hline CCSM4 RCP4.5 & 80 & 55 & 197.1 & 122 & 330 & 0.75 & 300 & 0.5 & \multirow{4}{*}{0.43} \\
\hline ECHAM6 RCP4.5 & 80 & 55 & 177.7 & 110 & 215 & 0.75 & 185 & 0.5 & \\
\hline CCSM4 RCP8.5 & 80 & 55 & 229.9 & 122 & 260 & 0.75 & 230 & 0.5 & \\
\hline ECHAM6 RCP8.5 & 80 & 55 & 264.3 & 120 & 250 & 0.75 & 220 & 0.5 & \\
\hline \multicolumn{10}{|c|}{ Short-term (2010-39) } \\
\hline CCSM4 RCP4.5 & 70 & 30 & 131.0 & 85 & 180 & 0.9 & 150 & 0.8 & \multirow{4}{*}{0.58} \\
\hline ECHAM6 RCP4.5 & 70 & 30 & 123.2 & 70 & - & - & - & - & \\
\hline CCSM4 RCP8.5 & 70 & 30 & 133.3 & 90 & 180 & 0.9 & 150 & 0.8 & \\
\hline ECHAM6 RCP8.5 & 70 & 30 & 116.5 & 90 & 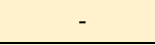 & - & - & - & \\
\hline \multicolumn{10}{|c|}{ Medium-term (2040-69) } \\
\hline CCSM4 RCP4.5 & 75 & 55 & 140.0 & 100 & 190 & 0.9 & 160 & 0.8 & \multirow{4}{*}{0.58} \\
\hline ECHAM6 RCP4.5 & 75 & 55 & 137.7 & 95 & - & - & - & - & \\
\hline CCSM4 RCP8.5 & 75 & 55 & 155.7 & 100 & 300 & 0.9 & 270 & 0.6 & \\
\hline ECHAM6 RCP8.5 & 75 & 55 & 152.3 & 95 & 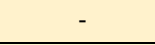 & - & - & - & \\
\hline \multicolumn{10}{|c|}{ Long-term (2070-99) } \\
\hline CCSM4 RCP4.5 & 80 & 55 & 147.8 & 110 & 200 & 0.9 & 180 & 0.8 & \multirow{4}{*}{0.58} \\
\hline ECHAM6 RCP4.5 & 80 & 55 & 133.3 & 110 & - & - & - & - & \\
\hline CCSM4 RCP8.5 & 80 & 55 & 172.4 & 110 & - & - & - & - & \\
\hline ECHAM6 RCP8.5 & 80 & 55 & 198.2 & 120 & - & - & - & - & \\
\hline \multicolumn{10}{|c|}{ Short-term (2010-39) } \\
\hline CCSM4 RCP4.5 & 70 & 30 & 116.5 & 85 & - & - & - & - & \\
\hline ECHAM6 RCP4.5 & 70 & 30 & 109.5 & 70 & - & - & - & - & 065 \\
\hline CCSM4 RCP8.5 & 70 & 30 & 118.4 & 90 & - & - & - & - & \\
\hline ECHAM6 RCP8.5 & 70 & 30 & 103.5 & 90 & - & - & - & - & \\
\hline & & & & Medium-term & $(2040-69)$ & & & & \\
\hline CCSM4 RCP4.5 & 75 & 55 & 124.4 & 100 & - & - & - & - & \\
\hline ECHAM6 RCP4.5 & 75 & 55 & 122.4 & 95 & - & - & - & - & 065 \\
\hline CCSM4 RCP8.5 & 75 & 55 & 138.4 & 100 & - & - & 190 & 0.9 & \\
\hline ECHAM6 RCP8.5 & 75 & 55 & 135.4 & 95 & - & - & - & - & \\
\hline & & & & Long-term ( & 2070-99) & & & & \\
\hline CCSM4 RCP4.5 & 80 & 55 & 131.4 & 110 & - & - & - & - & \\
\hline ECHAM6 RCP4.5 & 80 & 55 & 118.4 & 110 & - & - & - & - & 065 \\
\hline CCSM4 RCP8.5 & 80 & 55 & 153.3 & 110 & - & - & - & - & \\
\hline ECHAM6 RCP8.5 & 80 & 55 & 176.2 & 120 & - & - & - & - & \\
\hline
\end{tabular}

Table 5. - Adaptation measure considering the effect of climate change in the historic agricultural demand (7250 ha), the colours indicate the simulation c (blue), $d$ (orange) and e (green) of the Table 4. 


\subsubsection{Irrigation expansion projects assessment}

The Carrizal Chone irrigation system built in 2007 is designed to irrigate 13,268 hectares in its operational phase. However, under a climate change context, the system does not work with 13,268 hectares. To expand irrigation areas, the system must use a 0.73 irrigation efficiency. The increase in hectares is given depending on the models, scenarios and periods. (Table 6). The irrigation efficiencies are product result between the driving efficiency, distribution efficiency and application efficiency (Jensen, 2007; Whittlesey, 2003). Fujihara et al., (2008) claim that, if the irrigated area is expanded in the future under the expectation of current flow, water scarcity will occur.

\begin{tabular}{lccc}
\hline \hline \multicolumn{4}{c}{ Maximum future irrigation areas } \\
\hline \hline Model and Scenario & Short term & Medium term & Long term \\
\hline \hline CCSM4 RCP4.5 & 11250 & 9100 & 8500 \\
ECHAM6 RCP4.5 & 13300 & 10900 & 11500 \\
CCSM4 RCP8.5 & 11350 & 8200 & 10300 \\
ECHAM6 RCP8.5 & 13300 & 11500 & 9700 \\
\hline \hline
\end{tabular}

Table 6. Maximum expansion of agricultural area with irrigation efficiency of 0.73 for study area. Values in hectares (ha).

These results show that, under the effect of climate change, deficits may occur and therefore noncompliance with the guarantee criteria for supplying agricultural demand. With the increase in temperature being the primary cause of these non-compliances because even by increasing contribution, the available water is not enough to satisfy the future water demands. Applying operational measures in the water resources management of the exploitation systems and improving irrigation efficiency. Otherwise, the underground water resource should be incorporated into the management of the exploitation system, or new storage structures should be added in the system (Gutiérrez et al., 2014; Paola et al., 2013). Another option is the replacement of seasonal crops in the dry season, for crops that require an amount of water less than current crops, without affecting the food security of the region. For the developed of future expansion projects for irrigated areas in the Manabí River Basin District it should be considered the effect of climate change on water resources and to use an 0.73 irrigation efficiency. For decision making, it should be considered that agriculture is one of the most crucial activities for the economic development of the River Basin District. Park et al., (2009) assessed the climate change impact on the temporal variation of water levels in paddy rice irrigation reservoirs, and adjusted reservoir releases in August and September as a future 
adaption strategy. The results of the future impact showed that the future reservoir storages of autumn and winter season after completion of the irrigation period decreased for 2080. Therefore, as a future adaptation strategy, the control of reservoir release, by decreasing in August and September, could secure the reservoir water level in autumn and winter season by reaching the water level to almost $100 \%$ of the present reservoir water level management. Ncube et al., (2011) evaluated reservoir operation under variable climate scenarios. Results show that the reservoir can satisfy current demands but will fail to cope with the forecasted increase in demand. The predicted level of climate change will result in shortages of up to $30 \%$ for the downstream users needing to review how the reservoir is operated. 


\section{CONCLUSIONS}

In the study basins CCSM4 and ECHAM6 models coincide with the increase of the precipitation in the dry season, while in the wet season a slight decrease is projected with the CCSM4 model and an increase with the ECHAM6 model. Both models indicate a progressive intensification of temperature in the short, medium and long term in all scenarios, being the lightest RCP4.5 and the most severe RCP8.5. These increases show an impact on real evapotranspiration and potential evapotranspiration.

The PET calculations by Penman Monteith and Thornthwaite methods show similar results under the current climate $126 \mathrm{~mm} / \mathrm{month}$ and $123 \mathrm{~mm} / \mathrm{month}$ respectively, however under climate change, Thornthwaite method gives results significantly higher $(211 \mathrm{~mm} / \mathrm{month})$ regarding to Penman Monteith method (144 mm/month). This study shows that, in tropical basins the use of Thornthwaite can give results excessive. Therefore, given that the demands calculation is based in the evapotranspiration potential, it is recommended to use the Penman-Monteith method to the demand calculation.

The simulation results carried out indicate that, in the dry season, more water will be required to satisfy the potential evapotranspiration. The requirements fluctuate between $7 \%$ and $81 \%$ (PET Th), and until 4\% (PET P-M), according to the water requirements of the analysed historical series. Besides, it is expected that in the first months of the wet season there will be water requirements due to a minimum increase in precipitation and temperature increases. Based on PET Th, the CCSM4 model shows a reduction in streamflow in wet and dry seasons, except for RCP8.5 scenarios in the 2070-2099 period, where increases are observed in both seasons. The simulation results with ECHAM6 indicate that increases in the wet season are expected, except for the RCP8.5 scenario in the 2010-39 period. In the dry season, it is expected t hat streamflow will increase by a maximum of $14 \%\left(1 \mathrm{hm}^{3}\right)$ according to the historical streamflow of baseline. While, results based on PET P-M indicate increase in streamflow in wet and dry seasons for all simulations from 3\% until 30\%.

The analysis of the Carrizal River exploitation system in the baseline indicate which the system met 100\% GM, GA and GV and with 0\% UTAH criteria $(1,2,10)$ for the DU, DA and Qec, and which, in current climate conditions the irrigation system can to expands by until 24,000 hectares. Under the effect of climate 
change (RCP4.5, 8.5) according to the ECHAM6 and CCSM4 models, the results show which, to the medium and long term the resources stored in the infrastructure of basin are not enough to supply the agricultural demand increase. Therefore, under the critical scenario (PET Th) the irrigation system can not to expand the irrigation areas to 13,268 . To make the system work is established to improve the urban and agricultural management and improving the distribution and application efficiency of irrigation systems. So, it is established, to keep a reserve curve that varies from 90 to $120 \mathrm{hm}^{3}$ until the end of the century in the reservoir $\left(450 \mathrm{hm}^{3}\right)$ and achieve an irrigation efficiency from 0.43 to 0.65 . For the developed of future expansion projects for irrigated areas it should be considered the effect of climate change on water resources and to use an 0.73 irrigation efficiency. Applying operational measures in the water resources management of the exploitation systems and improving irrigation efficiency, vulnerability to climate change can be reduced.

\section{ACKNOWLEDGMENT}

The authors thank the Secretariat of Higher Education, Science, Technology and Innovation of Ecuador (Secretaría de Educación Superior, Ciencia, Tecnología e Innovación, SENESCYT) for funding this research in the scholarship program: “CONVOCATORIA ABIERTA 2011” (contract AR2Q-4308).

We would also like to express our gratitude to the National Institute of Meteorology and Hydrology (Instituto Nacional de Meteorología e Hidrología - INAMHI), National Secretary of Water (Secretaría Nacional del Agua - SENAGUA) and Geographic Military Institute (Instituto Geográfico Militar - IGM) of Ecuador for providing data to develop this study. 


\section{REFERENCES}

Acharjee, T.K., Ludwig, F., van Halsema, G., Hellegers, P., Supit, I., 2017. Future changes in water requirements of Boro rice in the face of climate change in North-West Bangladesh. Agric. Water Manag. 194, 172-183. https://doi.org/10.1016/j.agwat.2017.09.008

Ahmadi, M., Haddad, O.B., Loáiciga, H.A., 2015. Adaptive Reservoir Operation Rules Under Climatic Change. Water Resour. Manag. 29, 1247-1266. https://doi.org/10.1007/s11269-014-0871-0

Alcamo, J., Flörke, M., Märker, M., 2007. Future long-term changes in global water resources driven by socio-economic and climatic changes. Hydrol. Sci. J. 52, 247-275. https://doi.org/10.1623/hysj.52.2.247

Allen, M.R., Ingram, W.J., 2002. Constraints on future changes in climate and the hydrologic cycle. Nature 419, 224-232.

ALLEN, R.G., 1994. An update for the calculation of reference evapotranspiration. ICID Bull 43, 35-92.

Arnell, N.W., 2010. Adapting to climate change: an evolving research programme. Clim. Change 100, 107111.

Arnell, N.W., van Vuuren, D.P., Isaac, M., 2011. The implications of climate policy for the impacts of climate change on global water resources. Glob. Environ. Change 21, 592-603.

Bates, B., Kundzewicz, Z., Wu, S., 2008. Climate change and water. Intergovernmental Panel on Climate Change Secretariat.

Bhatta, B., Shrestha, S., Shrestha, P.K., Talchabhadel, R., 2019a. Evaluation and application of a SWAT model to assess the climate change impact on the hydrology of the Himalayan River Basin. CATENA 181, 104082. https://doi.org/10.1016/j.catena.2019.104082

Bhatta, B., Shrestha, S., Shrestha, P.K., Talchabhadel, R., 2019b. Evaluation and application of a SWAT model to assess the climate change impact on the hydrology of the Himalayan River Basin. CATENA 181, 104082. https://doi.org/10.1016/j.catena.2019.104082

Bhave, A.G., Mishra, A., Raghuwanshi, N.S., 2014. A combined bottom-up and top-down approach for assessment of climate change adaptation options. J. Hydrol., Creating Partnerships Between Hydrology and Social Science: A Priority for Progress 518, 150-161. https://doi.org/10.1016/j.jhydrol.2013.08.039

Camargo, A.P., Marin, F.R., Sentelhas, P.C., Picini, A.G., 1999. Adjust of the Thornthwaite's method to estimate the potential evapotranspiration for arid and superhumid climates, based on daily temperature amplitude. Rev Bras Agrometeorol 7, 251-257.

Chung, S.-O., Nkomozepi, T., 2012. Uncertainty of paddy irrigation requirement estimated from climate change projections in the Geumho river basin, Korea. Paddy Water Environ. 10, 175-185. https://doi.org/10.1007/s10333-011-0305-z

Clarke, L., Edmonds, J., Jacoby, H., Pitcher, H., Reilly, J., Richels, R., 2007. Scenarios of greenhouse gas emissions and atmospheric concentrations. US Dep. Energy Publ. 6.

Cudennec, C., Leduc, C., Koutsoyiannis, D., 2007. Dryland hydrology in Mediterranean regions—a review. Hydrol. Sci. JournalJournal Sci. Hydrol. 52, 1077-1087.

De Silva, C.S., Weatherhead, E.K., Knox, J.W., Rodriguez-Diaz, J.A., 2007. Predicting the impacts of climate change-A case study of paddy irrigation water requirements in Sri Lanka. Agric. Water Manag. 93, 19-29. https://doi.org/10.1016/j.agwat.2007.06.003

Döll, P., 2002. Impact of Climate Change and Variability on Irrigation Requirements: A Global Perspective. Clim. Change 54, 269-293. https://doi.org/10.1023/A:1016124032231

Estrada, F., 1994. Garantía en los sistemas de explotación de los recursos hidráulicos. Madr. Cent. Estud. Exp. En Obras Hidráulicas Minist. Obras Públicas Transp. Medio Ambiente. 
Estrela, T., 1992. Modelos matemáticos para la evaluación de recursos hídricos. CEDEX.

Estrela, T., Pérez-Martin, M.A., Vargas, E., 2012. Impacts of climate change on water resources in Spain. Hydrol. Sci. J. 57, 1154-1167. https://doi.org/10.1080/02626667.2012.702213

Eum, H.-I., Simonovic, S.P., 2010. Integrated Reservoir Management System for Adaptation to Climate Change: The Nakdong River Basin in Korea. Water Resour. Manag. 24, 3397-3417. https://doi.org/10.1007/s11269-010-9612-1

Fasakhodi, A.A., Nouri, S.H., Amini, M., 2010. Water resources sustainability and optimal cropping pattern in farming systems; a multi-objective fractional goal programming approach. Water Resour. Manag. 24, 4639-4657.

Fischer, E.M., Seneviratne, S.I., Vidale, P.L., Lüthi, D., Schär, C., 2007. Soil moisture-atmosphere interactions during the 2003 European summer heat wave. J. Clim. 20, 5081-5099.

Fu, G.B., Charles, S.P., Yu, J.J., 2009. A critical overview of pan evaporation trends over the last 50 years. Clim. Change 97, 193-214. https://doi.org/10.1007/s10584-009-9579-1

Fujihara, Y., Tanaka, K., Watanabe, T., Nagano, T., Kojiri, T., 2008. Assessing the impacts of climate change on the water resources of the Seyhan River Basin in Turkey: Use of dynamically downscaled data for hydrologic simulations. J. Hydrol. 353, 33-48. https://doi.org/10.1016/j.jhydrol.2008.01.024

García-Ruiz, J.M., López-Moreno, J.I., Vicente-Serrano, S.M., Lasanta-Martínez, T., Beguería, S., 2011. Mediterranean water resources in a global change scenario. Earth-Sci. Rev. 105, 121-139.

Gebrechorkos, S.H., Bernhofer, C., Hülsmann, S., 2019. Impacts of projected change in climate on water balance in basins of East Africa. Sci. Total Environ. 682, 160-170. https://doi.org/10.1016/j.scitotenv.2019.05.053

Gent, P.R., Danabasoglu, G., Donner, L.J., Holland, M.M., Hunke, E.C., Jayne, S.R., Lawrence, D.M., Neale, R.B., Rasch, P.J., Vertenstein, M., Worley, P.H., Yang, Z.-L., Zhang, M., 2011. The Community Climate System Model Version 4. J. Clim. 24, 4973-4991. https://doi.org/10.1175/2011JCLI4083.1

Georgakakos, A.P., Yao, H., Kistenmacher, M., Georgakakos, K.P., Graham, N.E., Cheng, F.-Y., Spencer, C., Shamir, E., 2012. Value of adaptive water resources management in Northern California under climatic variability and change: Reservoir management. J. Hydrol., Hydrology Conference 2010412 413, 34-46. https://doi.org/10.1016/j.jhydrol.2011.04.038

Georgiou, P.E., Papamichail, D.M., 2008. Optimization model of an irrigation reservoir for water allocation and crop planning under various weather conditions. Irrig. Sci. 26, 487-504. https://doi.org/10.1007/s00271-008-0110-7

Gharbia, S.S., Smullen, T., Gill, L., Johnston, P., Pilla, F., 2018. Spatially distributed potential evapotranspiration modeling and climate projections. Sci. Total Environ. 633, 571-592. https://doi.org/10.1016/j.scitotenv.2018.03.208

Gómez-Martínez, G., Pérez-Martín, M.A., Estrela-Monreal, T., del-Amo, P., 2018. North Atlantic Oscillation as a Cause of the Hydrological Changes in the Mediterranean (Júcar River, Spain). Water Resour. Manag. 1-18. https://doi.org/10.1007/s11269-018-1954-0

Gondim, R., A.H. de Castro, M., Maia, A., Evangelista, S., Fuck Jr, S., 2012. Climate Change Impacts on Irrigation Water Needs in the jaguaribe River Basin. JAWRA J. Am. Water Resour. Assoc. 48. https://doi.org/10.1111/j.1752-1688.2011.00620.x

González-Zeas, D., Erazo, B., Lloret, P., De Bièvre, B., Steinschneider, S., Dangles, O., 2019. Linking global climate change to local water availability: Limitations and prospects for a tropical mountain watershed. Sci. Total Environ. 650, 2577-2586. https://doi.org/10.1016/j.scitotenv.2018.09.309

Guo, Y., Shen, Y., 2016. Agricultural water supply/demand changes under projected future climate change in the arid region of northwestern China. J. Hydrol. 540, 257-273. https://doi.org/10.1016/j.jhydrol.2016.06.033 
Gutiérrez, A.P.A., Engle, N.L., De Nys, E., Molejón, C., Martins, E.S., 2014. Drought preparedness in Brazil. Weather Clim. Extrem., High Level Meeting on National Drought Policy 3, 95-106. https://doi.org/10.1016/j.wace.2013.12.001

Hashemi, F., Habibian, M.T., 1979. Limitations of temperature-based methods in estimating crop evapotranspiration in arid-zone agricultural development projects. Agric. Meteorol. 20, 237-247. https://doi.org/10.1016/0002-1571(79)90025-6

Held, I.M., Soden, B.J., 2006. Robust responses of the hydrological cycle to global warming. J. Clim. 19, 5686-5699.

Hijioka, Y., Lin, E., Pereira, J., Corlett, R.T., Cui, X., Insarov, G.E., Lindgren, E., Surjan, A., 2014. Asia. In: Climate Change 2014: Impacts, Adaptation, and Vulnerability. Part B: Regional Aspects. Contribution of Working Group II to the Fifth Assessment Report of the Intergovernmental Panel on Climate Change [Barros, V.R., C.B. Field, D.J. Dokken, M.D. Mastrandrea, K.J. Mach, T.E. Bilir, M. Chatterjee, K.L. Ebi, Y.O. Estrada, R.C. Genova, B. Girma, E.S. Kissel, A.N. Levy, S. MacCracken, P.R. Mastrandrea, and L.L.White (eds.)]. Cambridge University Press, Cambridge, United Kingdom and New York, NY, USA, pp. 1327-1370.

Huang, S., Wortmann, M., Duethmann, D., Menz, C., Shi, F., Zhao, C., Su, B., Krysanova, V., 2018. Adaptation strategies of agriculture and water management to climate change in the Upper Tarim River basin, NW China. Agric. Water Manag. 203, 207-224. https://doi.org/10.1016/j.agwat.2018.03.004

Huntington, T.G., 2010. Chapter One - Climate Warming-Induced Intensification of the Hydrologic Cycle: An Assessment of the Published Record and Potential Impacts on Agriculture, in: Sparks, D.L. (Ed.), Advances in Agronomy. Academic Press, pp. 1-53. https://doi.org/10.1016/B978-0-12-3850409.00001-3

Iglesias, A., Garrote, L., 2015. Adaptation strategies for agricultural water management under climate change in Europe. Agric. Water Manag. 155, 113-124. https://doi.org/10.1016/j.agwat.2015.03.014

IPCC, 2014. Climate Change 2014: Impacts, Adaptation, and Vulnerability. Part A: Global and Sectoral Aspects. Contribution of Working Group II to the Fifth Assessment Report of the Intergovernmental Panel on Climate Change [Field, C.B., V.R. Barros, D.J. Dokken, K.J. Mach, M.D. Mastrandrea, T.E. Bilir, M. Chatterjee, K.L. Ebi, Y.O. Estrada, R.C. Genova, B. Girma, E.S. Kissel, A.N. Levy, S. MacCracken, P.R. Mastrandrea, and L.L.White (eds.)]. Cambridge University Press, Cambridge, United Kingdom and New York, NY, USA, 1132 pp.

IPCC, 2013. Climate Change 2013: The Physical Science Basis. Contribution of Working Group I to the Fifth Assessment Report of the Intergovernmental Panel on Climate Change [Stocker, T.F., D. Qin, G.-K. Plattner, M. Tignor, S.K. Allen, J. Boschung, A. Nauels, Y. Xia, V. Bex and P.M. Midgley (eds.)]. Cambridge University Press, Cambridge, United Kingdom and New York, NY, USA, 1535 pp.

IPCC, 2007a. Climate Change 2007: The Physical Science Basis. Contribution of Working Group I to the Fourth Assessment Report of the Intergovernmental Panel on Climate Change [Solomon, S., D. Qin, M. Manning, Z. Chen, M. Marquis, K.B. Averyt, M. Tignor and H.L. Miller (eds.)]. Cambridge University Press, Cambridge, United Kingdom and New York, NY, USA. 996 pp.

IPCC, 2007b. Climate change 2007: Synthesis report. Contribution of Working groups I, II and III to the Fourth Assessment report of the Intergovernmental panel on climate change.

Jensen, M.E., 2007. Beyond irrigation efficiency. Irrig. Sci. 25, 233-245. https://doi.org/10.1007/s00271007-0060-5

Jiménez Cisneros, B.E., Oki, T., Arnell, N.W., Benito, G., Cogley, J.G., Doll, P., Jiang, T., Mwakalila, S.S., 2014. Freshwater resources In: Climate Change 2014: Impacts,Adaptation, and Vulnerability. Part A: Global and Sectoral Aspects. Contribution of Working Group II to the Fifth Assessment Report of the Intergovernmental Panel on Climate Change [Field, C.B., V.R. Barros, D.J. Dokken, K.J. Mach, 
M.D. Mastrandrea, T.E. Bilir, M. Chatterjee, K.L. Ebi, Y.O. Estrada, R.C. Genova, B. Girma, E.S. Kissel, A.N. Levy, S. MacCracken, P.R. Mastrandrea, and L.L.White (eds.)]. Cambridge University Press, Cambridge, United Kingdom and New York, NY, USA, pp. 229-269.

Jódar, J., Cabrera, J.A., Martos-Rosillo, S., Ruiz-Constán, A., González-Ramón, A., Lambán, L.J., Herrera, C., Custodio, E., 2017. Groundwater discharge in high-mountain watersheds: A valuable resource for downstream semi-arid zones. The case of the Bérchules River in Sierra Nevada (Southern Spain). Sci. Total Environ. 593-594, 760-772. https://doi.org/10.1016/j.scitotenv.2017.03.190

Kirby, J.M., Connor, J., Ahmad, M.D., Gao, L., Mainuddin, M., 2014. Climate change and environmental water reallocation in the Murray-Darling Basin: Impacts on flows, diversions and economic returns to irrigation. J. Hydrol., Creating Partnerships Between Hydrology and Social Science: A Priority for Progress 518, 120-129. https://doi.org/10.1016/j.jhydrol.2014.01.024

Kling, H., Stanzel, P., Preishuber, M., 2014. Impact modelling of water resources development and climate scenarios on Zambezi River discharge. J. Hydrol. Reg. Stud. 1, 17-43. https://doi.org/10.1016/j.ejrh.2014.05.002

Knox, J.W., Rodríguez Díaz, J.A., Nixon, D.J., Mkhwanazi, M., 2010. A preliminary assessment of climate change impacts on sugarcane in Swaziland. Agric. Syst. 103, 63-72. https://doi.org/10.1016/j.agsy.2009.09.002

Kumar, N., Tischbein, B., Kusche, J., Laux, P., Beg, M.K., Bogardi, J.J., 2017. Impact of climate change on water resources of upper Kharun catchment in Chhattisgarh, India. J. Hydrol. Reg. Stud. 13, 189207. https://doi.org/10.1016/j.ejrh.2017.07.008

Kundzewicz, Z.W., Mata, L.J., Arnell, N.W., Döll, P., Kabat, P., Jiménez, B., Miller, K.A., Oki, T., Sen, Z., Shiklomanov, I.A., 2007. Freshwater resources and their management, in: Climate Change 2007: Impacts, Adaptation and Vulnerability. Contribution of Working Group II to the Fourth Assessment Report of the Intergovernmental Panel on Climate Change. Cambridge University Press, Cambridge, United Kingdom and New York, NY, USA.

Lall, U., Miller, C.W., 1988. An optimization model for screening multipurpose reservoir systems. Water Resour. Res. 24, 953-968. https://doi.org/10.1029/WR024i007p00953

Li, Z., Zheng, F.-L., Liu, W.-Z., 2012. Spatiotemporal characteristics of reference evapotranspiration during 1961-2009 and its projected changes during 2011-2099 on the Loess Plateau of China. Agric. For. Meteorol. 154-155, 147-155. https://doi.org/10.1016/j.agrformet.2011.10.019

Lindström, G., Bergström, S., 2004. Runoff trends in Sweden 1807-2002 / Tendances de l'écoulement en Suède entre 1807 et 2002. Hydrol. Sci. J. 49, 69-83. https://doi.org/10.1623/hysj.49.1.69.54000

Liu, P., Li, L., Guo, S., Xiong, L., Zhang, W., Zhang, J., Xu, C.-Y., 2015. Optimal design of seasonal flood limited water levels and its application for the Three Gorges Reservoir. J. Hydrol. 527, 1045-1053. https://doi.org/10.1016/j.jhydrol.2015.05.055

Magrin, G.O., Marengo, J.A., Boulanger, J.P., Buckeridge, M.S., Castellanos, E., Poveda, G., Scarano, F.R., Vicuña, S., 2014. Central and South America . In: Climate Change 2014: Impacts, Adaptation, and Vulnerability. Part B: Regional Aspects. Contribution of Working Group II to the Fifth Assessment Report of the Intergovernmental Panel on Climate Change [Barros, V.R., C.B. Field, D.J. Dokken, M.D. Mastrandrea, K.J. Mach, T.E. Bilir, M. Chatterjee, K.L. Ebi, Y.O. Estrada, R.C. Genova, B. Girma, E.S. Kissel, A.N. Levy, S. MacCracken, P.R. Mastrandrea, and L.L.White (eds.)]. Cambridge University Press, Cambridge, United Kingdom and New York, NY, USA, pp. 1499-1566. pp. 1499_ 1566.

Majone, B., Bovolo, C.I., Bellin, A., Blenkinsop, S., Fowler, H.J., 2012. Modeling the impacts of future climate change on water resources for the Gállego river basin (Spain). Water Resour. Res. 48. https://doi.org/10.1029/2011WR010985

Malek, E., 1987. Comparison of alternative methods for estimating ETp and evaluation of advection in the Bajgah area, Iran. Agric. For. Meteorol. 39, 185-192. https://doi.org/10.1016/0168-1923(87)90036- 
Malek, K., Adam, J.C., Stöckle, C.O., Peters, R.T., 2018. Climate change reduces water availability for agriculture by decreasing non-evaporative irrigation losses. J. Hydrol. 561, 444-460. https://doi.org/10.1016/j.jhydrol.2017.11.046

Mall, R.K., Gupta, A., Sonkar, G., 2017. 2 - Effect of Climate Change on Agricultural Crops, in: Current Developments in Biotechnology and Bioengineering. Elsevier, pp. 23-46. https://doi.org/10.1016/B978-0-444-63661-4.00002-5

Marcos-Garcia, P., Lopez-Nicolas, A., Pulido-Velazquez, M., 2017. Combined use of relative drought indices to analyze climate change impact on meteorological and hydrological droughts in a Mediterranean basin. J. Hydrol. 554, 292-305. https://doi.org/10.1016/j.jhydrol.2017.09.028

Moriasi, D., Gitau, M., Pai, N., Daggupati, P., 2015. Hydrologic and Water Quality Models: Performance Measures and Evaluation Criteria. Trans. ASABE Am. Soc. Agric. Biol. Eng. 58, 1763-1785. https://doi.org/10.13031/trans.58.10715

Mosquera-Machado, S., Ahmad, S., 2007. Flood hazard assessment of Atrato River in Colombia. Water Resour. Manag. 21, 591-609. https://doi.org/10.1007/s11269-006-9032-4

Nam, W.-H., Choi, J.-Y., 2014. Development of an irrigation vulnerability assessment model in agricultural reservoirs utilizing probability theory and reliability analysis. Agric. Water Manag. 142, 115-126. https://doi.org/10.1016/j.agwat.2014.05.009

Ncube, S.P., Makurira, H., Kaseke, E., Mhizha, A., 2011. Reservoir operation under variable climate: Case of Rozva Dam, Zimbabwe. Phys. Chem. Earth Parts ABC, 11th WaterNet/WARFSA/GWP-SA Symposium: IWRM for National and Regional Integration through Science, Policy and Practice 36, 1112-1119. https://doi.org/10.1016/j.pce.2011.07.059

Niang, I., Ruppel, O.C., Abdrabo, M.A., Essel, A., Lennard, C., Padgham, J., Urquhart, P., 2014. Africa, In: Climate Change 2014: Impacts, Adaptation, and Vulnerability. Part B: Regional Aspects. Contribution of Working Group II to the Fifth Assessment Report of the Intergovernmental Panel on Climate Change [Barros, V.R., C.B. Field, D.J. Dokken, M.D. Mastrandrea, K.J. Mach, T.E. Bilir, M. Chatterjee, K.L. Ebi, Y.O. Estrada, R.C. Genova, B. Girma, E.S. Kissel, A.N. Levy, S. MacCracken, P.R. Mastrandrea, and L.L.White (eds.)]. Cambridge University Press, Cambridge, United Kingdom and New York, NY, USA, pp. 1199-1265.

Nkomozepi, T., Chung, S.-O., 2014. The effects of climate change on the water resources of the Geumho River Basin, Republic of Korea. J. Hydro-Environ. Res. 8, 358-366. https://doi.org/10.1016/j.jher.2013.08.006

Nkomozepi, T., Chung, S.-O., 2012. Assessing the trends and uncertainty of maize net irrigation water requirement estimated from climate change projections for Zimbabwe. Agric. Water Manag. 111, 6067. https://doi.org/10.1016/j.agwat.2012.05.004

Paola, F. de, Ranucci, A., Feo, A., 2013. Antecedent Moisture Condition (scs) Frequency Assessment: A Case Study in Southern Italy. Irrig. Drain. 62, 61-71. https://doi.org/10.1002/ird.1801

Pardo-Igúzquiza, E., Collados-Lara, A.J., Pulido-Velazquez, D., 2019. Potential future impact of climate change on recharge in the Sierra de las Nieves (southern Spain) high-relief karst aquifer using regional climate models and statistical corrections. Environ. Earth Sci. 78, 598. https://doi.org/10.1007/s12665-019-8594-4

Paredes, J., Solera, A., Andreu, J., 2008. Reglas de operación para sistemas multiembalse, combinando métodos heurísticos y redes de flujo. Tecnol. Cienc. Agua 23, 151-164.

Park, G.-A., Shin, H.-J., Lee, M.-S., Hong, W.-Y., Kim, S.-J., 2009. Future potential impacts of climate change on agricultural watershed hydrology and the adaptation strategy of paddy rice irrigation reservoir by release control. Paddy Water Environ. 7, 271. https://doi.org/10.1007/s10333-009-0174$\mathrm{x}$ 
Pelton, W.L., King, K.M., Tanner, C.B., 1960. An Evaluation of the Thornthwaite and Mean Temperature Methods for Determining Potential Evapotranspiration 1. Agron. J. 52, 387-395. https://doi.org/10.2134/agronj1960.00021962005200070006x

Pérez-Martín, M.A., Estrela, T., Andreu, J., Ferrer, J., 2014. Modeling Water Resources and River-Aquifer Interaction in the Júcar River Basin, Spain. Water Resour. Manag. 28, 4337-4358. https://doi.org/10.1007/s11269-014-0755-3

Porter, J.R., Xie, L., Challinor, A.J., Cochrane, K., Howden, S.M., Iqbal, M.M., Lobell, D.B., Travasso, M.I., Netra Chhetri, N.C., Garrett, K., 2014. Food security and food production systems. In: Climate Change 2014: Impacts, Adaptation, and Vulnerability. Part A: Global and Sectoral Aspects. Contribution of Working Group II to the Fifth Assessment Report of the Intergovernmental Panel on Climate Change [Field, C.B., V.R. Barros, D.J. Dokken, K.J. Mach, M.D. Mastrandrea, T.E. Bilir, M. Chatterjee, K.L. Ebi, Y.O. Estrada, R.C. Genova, B. Girma, E.S. Kissel, A.N. Levy, S. MacCracken, P.R. Mastrandrea, and L.L.White (eds.)]. Cambridge University Press, Cambridge, United Kingdom and New York, NY, USA, pp. 485-533.

Pourrut, P., 1983. Los climas del Ecuador: fundamentos explicativos, in: Los climas del Ecuador, Documentos de Investigacion - CEDIG. CEDIG, Quito, pp. 7-41.

Puri, S., Stephen, H., Ahmad, S., 2011. Relating TRMM precipitation radar land surface backscatter response to soil moisture in the Southern United States. J. Hydrol. 402, 115-125. https://doi.org/10.1016/j.jhydrol.2011.03.012

Räisänen, J., Räty, O., 2013. Projections of daily mean temperature variability in the future: cross-validation tests with ENSEMBLES regional climate simulations. Clim. Dyn. 41, 1553-1568. https://doi.org/10.1007/s00382-012-1515-9

Räty, O., Räisänen, J., Ylhäisi, J.S., 2014. Evaluation of delta change and bias correction methods for future daily precipitation: intermodel cross-validation using ENSEMBLES simulations. Clim. Dyn.

Riahi, K., Grübler, A., Nakicenovic, N., 2007. Scenarios of long-term socio-economic and environmental development under climate stabilization. Technol. Forecast. Soc. Change, Greenhouse Gases Integrated Assessment 74, 887-935. https://doi.org/10.1016/j.techfore.2006.05.026

Ríos, S.C., Zurita, S., Montalvo, V., 2016. Métodos de ajuste y homogenización de datos climáticos para determinar índice de humedad de Lang en la provincia de Manabí, Ecuador. La Técnica 94-106.

Rossel, F., 1997. Influencia de El Niño sobre los regimenes hidro-pluviométricos del Ecuador. Ser. INSEQ 18.

Savé, R., de Herralde, F., Aranda, X., Pla, E., Pascual, D., Funes, I., Biel, C., 2012. Potential changes in irrigation requirements and phenology of maize, apple trees and alfalfa under global change conditions in Fluvià watershed during XXIst century: Results from a modeling approximation to watershed-level water balance. Agric. Water Manag., For a better use and distribution of water 114, 78-87. https://doi.org/10.1016/j.agwat.2012.07.006

Shnaydman, V.M., 1993. The influence of climate variations on an irrigation water resources system performance strategy. Water Resour. Manag. 7, 39-56. https://doi.org/10.1007/BF00872241

Stevens, B., Giorgetta, M., Esch, M., Mauritsen, T., Crueger, T., Rast Sebastian, Salzmann Marc, Schmidt Hauke, Bader Jürgen, Block Karoline, Brokopf Renate, Fast Irina, Kinne Stefan, Kornblueh Luis, Lohmann Ulrike, Pincus Robert, Reichler Thomas, Roeckner Erich, 2013. Atmospheric component of the MPI-M Earth System Model: ECHAM6. J. Adv. Model. Earth Syst. 5, 146-172. https://doi.org/10.1002/jame.20015

Suárez-Almiñana, S., Pedro-Monzonís, M., Paredes-Arquiola, J., Andreu, J., Solera, A., 2017. Linking PanEuropean data to the local scale for decision making for global change and water scarcity within water resources planning and management. Sci. Total Environ. 603-604, 126-139. https://doi.org/10.1016/j.scitotenv.2017.05.259 
Tao, X., Chen, H., Xu, C., Hou, Y., Jie, M., 2015. Analysis and prediction of reference evapotranspiration with climate change in Xiangjiang River Basin, China. Water Sci. Eng. 8, 273-281. https://doi.org/10.1016/j.wse.2015.11.002

Témez, J., 1977. Modelo matemático de transformación “precipitación - escorrentía.” Asociación de Investigación Industrial Eléctrica ASINEL. Madrid: 39.

Thornthwaite, C.W., 1948. An Approach toward a Rational Classification of Climate. Geogr. Rev. 38, 5594. https://doi.org/10.2307/210739

van den Hurk, B.J.J.M., Bouwer, L.M., Buontempo, C., Döscher, R., Ercin, E., Hananel, C., Hunink, J.E., Kjellström, E., Klein, B., Manez, M., Pappenberger, F., Pouget, L., Ramos, M.-H., Ward, P.J., Weerts, A.H., Wijngaard, J.B., 2016. Improving predictions and management of hydrological extremes through climate services: www.imprex.eu. Clim. Serv. 1, 6-11. https://doi.org/10.1016/j.cliser.2016.01.001

Vargas, G., Rutllant, J., Ortlieb, L., 2006. ENSO tropical-extratropical climate teleconnections and mechanisms for Holocene debris flows along the hyperarid coast of western South America (17 24오). Earth Planet. Sci. Lett. 249, 467-483. https://doi.org/10.1016/j.epsl.2006.07.022

Vergara, W., Deeb, A.M., Valencia, A.M., Bradley, R.S., Francou, B., Zarzar, A., Grünwaldt, A., Haeussling, S.M., 2007. Economic Impacts of Rapid Glacier Retreat in the Andes. EOS Trans. 88, 261-264. https://doi.org/10.1029/2007EO250001

Vicente-Serrano, S.M., Aguilar, E., Martínez, R., Martín-Hernández, N., Azorin-Molina, C., SanchezLorenzo, A., Kenawy, A.E., Tomás-Burguera, M., Moran-Tejeda, E., López-Moreno, J.I., Revuelto, J., Beguería, S., Nieto, J.J., Drumond, A., Gimeno, L., Nieto, R., 2016. The complex influence of ENSO on droughts in Ecuador. Clim. Dyn. 48, 405-427. https://doi.org/10.1007/s00382-016-3082-y

Whittlesey, N., 2003. Improving irrigation efficiency through technology adoption: When will it Conserve water?, in: Alsharhan, A.S., Wood, W.W. (Eds.), Developments in Water Science, Water Resources Perspectives: Evaluation, Management and Policy. Elsevier, pp. 53-62. https://doi.org/10.1016/S0167-5648(03)80007-2

Xu, W., Zhao, J., Zhao, T., Wang, Z., 2014. Adaptive Reservoir Operation Model Incorporating Nonstationary Inflow Prediction. J. Water Resour. Plan. Manag. https://doi.org/10.1061/(ASCE)WR.1943-5452.0000502

Yang, G., Guo, S., Li, L., Hong, X., Wang, L., 2016. Multi-Objective Operating Rules for Danjiangkou Reservoir Under Climate Change. Water Resour. Manag. 30, 1183-1202. https://doi.org/10.1007/s11269-015-1220-7

Yang, Q., Ma, Z., Zheng, Z., Duan, Y., 2017. Sensitivity of potential evapotranspiration estimation to the Thornthwaite and Penman-Monteith methods in the study of global drylands. Adv. Atmospheric Sci. 34, 1381-1394. https://doi.org/10.1007/s00376-017-6313-1

Yeste, P., Dorador, J., Martin-Rosales, W., Molero, E., Esteban-Parra, M.J., Rueda, F.J., 2018. Climatedriven trends in the streamflow records of a reference hydrologic network in Southern Spain. J. Hydrol. 566, 55-72. https://doi.org/10.1016/j.jhydrol.2018.08.063

Zambrano Mera, Y.E., Rivadeneira Vera, J.F., Pérez-Martín, M.Á., 2018. Linking El Niño Southern Oscillation for early drought detection in tropical climates: The Ecuadorian coast. Sci. Total Environ. 643, 193-207. https://doi.org/10.1016/j.scitotenv.2018.06.160

Zhang, S., Zhang, J., Yue, T., Jing, X., 2019. Impacts of climate change on urban rainwater harvesting systems. Sci. Total Environ. 665, 262-274. https://doi.org/10.1016/j.scitotenv.2019.02.135

Zhou, Y., Guo, S., 2013. Incorporating ecological requirement into multipurpose reservoir operating rule curves for adaptation to climate change. J. Hydrol. 498, 153-164. https://doi.org/10.1016/j.jhydrol.2013.06.028 